\title{
Microstructures in subglacial and proglacial sediments: understanding faults, folds and fabrics, and the influence of water on the style of deformation
}

\author{
Emrys Phillips ${ }^{*}$, Jon Merritt, Clive Auton and Nick Golledge \\ British Geological Survey, Murchison House, West Mains Road, Edinburgh EH9 3LA, Scotland. \\ * Corresponding author. telephone: 0131-667-1000. fax: 0131-668-2683. e-mail: erp@bgs.ac.uk
}

\begin{abstract}
Macroscopic field and micromorphological studies have been carried out on subglacially and proglacially deformed glacigenic sequences at a number of sites throughout Scotland, UK. Examination of microstructures (folds, faults, hydrofractures, plasmic fabrics) aided understanding of the deformation histories preserved in the sediments, but a similar range of structures were developed in both subglacial and proglacial settings. Discrimination between subglacial and proglacial deformation was only possible when micromorphological data was used in conjunction with larger-scale field observations. Variations in lithology and water content were controlling factors influencing the style and apparent intensity of deformation recorded. Changes in pore-water content and pressure during deformation can lead to liquefaction and hydrofracturing, with early formed structures locally controlling the pattern of water-escape. Liquefaction can also lead to homogenisation of the sediments and the destruction of earlier deformation structures, even at relatively low strains. Beds or zones of liquefied sand and silt may form highly 'lubricated' detachments within the sediment pile, resulting in a marked reduction in the amount of shear transmitted to underlying units. A multidisciplinary approach, involving sedimentological, geomorphological, stratigraphical and structural field observations, combined with micromorphological analysis, is recommended to confidently unravel the glacitectonic history and depositional environment of most deformed glacigenic sedimentary sequences.
\end{abstract}

\section{Introduction}

Analysis of structural features (folds, faults, tectonic fabrics, stratification) preserved in subglacially and proglacially deformed sediments can provide important information characteristic of each type of glacier-induced deformation (e.g. McCarroll 
and Rijsdijk, 2003). In particular, the application of field and laboratory techniques routinely used by structural geologists can result in a systematic approach to investigation of complex polydeformed glacigenic sequences (e.g. Gijssel, 1986; van der Wateren, 1986; Phillips et al., 2002). This has led to a deeper understanding of tectonostratigraphical sequences and glacier-induced stresses responsible for their development (e.g. Berthelsen, 1978; Pedersen, 1993) than is possible from field observations alone. Research on glacitectonic structures also provides information on, and allows elucidation of, the nature of ice-marginal sedimentation and dynamics during glacial cycles (e.g. van der Wateren, 1986, 1995; Croot, 1988: Aber et al., 1989; Benn and Evans, 1993; Harris et al., 1997; Evans et al; 1999; Phillips et al., 2002; Hiemstra et al., 2005).

Micromorphological analysis is increasingly being used as a principal tool for distinguishing between subglacial and proglacial deformation and, in particular, between diamictons deposited in each environment (e.g. van der Meer et al., 2003; Menzies et al., 2006). The importance of its role increases where data from exposures is sparse such as in studies based on borehole cores (e.g. Carr et al., 2000, 2006). Analysis of thin sections in geological structural and metamorphic studies is a proven and well-established technique, providing a wealth of data on the geometry and kinematics of deformation. (see Bell and Rubenach, 1983; Vernon, 1989; Passchier and Trouw, 1996 and references therein). In contrast, the application of micromorphology to the interpretation of microstructures developed during subglacial and proglacial deformation is a relatively recent innovation (van der Meer and Laban, 1990; van der Meer et al., 1992, 1994; van der Meer, 1993; van der Meer and Warren, 1997; Menzies, 2000; Phillips and Auton, 2000; van der Wateren et al., 2000; Khatwa and Tulaczyk, 2001; Hart and Rose, 2001; Hiemstra and Rijsdijk, 2003; van der Meer et al., 2003; Menzies et al., 2006). The detailed analysis of thin sections is being used with increasing success to aid our understanding of both progressive and polyphase deformation of glacigenic sequences (e.g. van der Wateren, 1995; Phillips and Auton, 2000; van der Wateren et al., 2000). The role played by water during deformation is also increasingly being recognised (Boulton et al., 1974; Boulton, G.S. and Caban, P. 1995; Hiemstra and van der Meer, 1997; Rijsdijk et al., 1999; van der Meer et al., 1999; Phillips and Auton, 2000; Boulton et al., 2001; Khatwa and Tulaczyk, 2001; Phillips, 2006; Baroni and Fasano, 2006). 
This paper synthesises the results of field observations, sedimentological analyses and micromorphological studies from five sites from across Scotland. Its primary aims were:

- To establish some fundamental principles on how to approach micromorphological analysis of deformed glacigenic sequences;

- To critically evaluate micromorphology as a tool for distinguishing between the style of deformation in subglacial and proglacial settings;

- To unravel the complex deformation histories of polydeformed glacigenic sequences and relate the glacitectonic events to local patterns of ice movement.

As the work progressed, a fourth aim emerged; to evaluate the role of water in influencing the style, pervasiveness and intensity of deformation, and the preservation potential of microstructures.

\subsection{The sites}

The multidisciplinary studies have focused on subglacially deformed glaciolacustrine sediments and diamictons exposed at Raitts Burn in Strathspey and at Coire Mhic-sith near Drumochter; proglacially deformed glaciolacustrine/deltaic sediments from Glen Luibeg in the Cairngorm Mountains; subglacially deformed sands and an overlying diamicton from Plumpe Farm, near Gretna; and finally subglacial and proglacial deformed deltaic sandy sediments and associated diamictons from Drumbeg Quarry, near Drymen (Fig. 1). Micromorphological analysis has aided in the unravelling of the complex deformation histories recorded by these deposits and related these glacitectonic events to the local patterns of ice movement. The role of water as a factor controlling the style and intensity of deformation has also been investigated. The results of these Scottish studies are used to critically evaluate the potential for using micromorphological analysis to discriminate between subglacially and proglacially deformed sediments.

\section{Sample collection and analytical technique}

It is critical that correctly orientated samples are collected so that kinematic indicators (Choukroune et al., 1987; Passchier and Trouw, 1996; van der Wateren et al., 2000), 
such as the sense of asymmetry of folds, fabrics and boudins, as well as the sense of displacement faults, can be used to provide information on the stress regime active during deformation and local ice movement directions, as well as allow comparison with macroscopic fabric measurements. It is important that the orientation of the samples, relative to the presumed directions of ice advance and retreat be established. Only samples orientated parallel to the principal direction of ice movement will exhibit the most complete record of deformation and its intensity.

Prior to sampling the sedimentary sequences were logged and the macro-scale characteristics of the sequence (e.g. geometry of the units, lithology, macroscopic deformation structures....etc) were described in detail. Orientated samples of the glacigenic sediments were collected from Raitts Burn (3 samples), Coire Mhic-sith (3 samples), Glen Luibeg (2 samples), Plumpe Farm (4 samples) and Drumbeg Quarry (7 samples). Individual samples were collected using $10 \mathrm{~cm}$ square, aluminium kubiena tins, which were either cut or pushed into the face of each exposure in order to limit sample disturbance. The geographical position, orientation relative to magnetic north, depth and way-up of the sample were marked on the outside of the tin during collection. Each sample was then removed from the face, sealed in two plastic bags, and then stored in a cold store to prevent the material from drying out prior to sample preparation.

Sample preparation (total time c. 10 months) involved the initial replacement of porewater by acetone, which was then progressively replaced by a resin and allowed to cure. Large format orientated thin sections were taken from the centre of each of the prepared samples. Each thin section was cut orthogonal to the main deformation structures evident from the field investigation, thus avoiding artefacts associated with sample collection. The thin sections were examined using a standard Zeiss petrological microscope and Zeiss projector, the latter allowing detailed study of the range of microstructures at very low magnification. The terminology used to describe the various microtextures developed within these sediments in general follows that proposed by van der Meer (1987, 1993) and Menzies (2000). Successive generations of small-scale fabrics (S1, S2,....Sn), folds (F1, F2....Fn) and faults and their interrelationships are, typically, more clearly observed in thin section that at outcrop can be used to understand the deformation histories recorded by deformed glacigenic 
sequences. The various generations of deformation structures are distinguished by the nomenclature normally used in structural geological studies (e.g. S1 earliest fabric to Sn latest) (cf. Phillips and Auton, 2000).

\section{Subglacially deformed glaciolacustrine sediments and diamictons}

\subsection{Raitts Burn, Strathspey}

Glacial deposits exposed in Raitts Burn [National Grid Reference NH 780 041], Strathspey (Fig. 1) include deformed rhythmically laminated, glaciolacustrine finegrained sediments, interbedded with ice-proximal diamictons and gravels (Fig. 2). The Quaternary geology and geomorphology of Raitts Burn are summarised here; a more detailed description is presented in Phillips and Auton (2000). The main regional ice movement direction in Strathspey was towards the northeast (Young, 1978; Auton, 1998). The glaciolacustrine sediments were deposited within a small lake impounded by ice at the mouth of the valley of Raitts Burn. They are overlain by a sandy diamicton (or 'tectomict' of Menzies et al., 2006) that forms moraines, which are dissected by arcuate glacial drainage channels. The moraines formed at successive still-stand positions of a southerly retreating ice margin.

The poorly stratified, clast-supported, matrix-rich boulder and cobble gravel (Unit I, Fig. 2) at the base of the sequence is interpreted as an ice-proximal debris-flow or fan deposit, laid down during the initial deglaciation of the immediate Raitts Burn area (Phillips and Auton, 2000). The overlying rhythmically laminated silts and clays with occasional thin sandy interbeds (Unit II; Fig. 2) were all deposited in the ice-dammed lake. The upper most unit (Unit III; Fig. 2) comprises thick, weakly stratified sandy diamicton forming a push moraine. The intensity of deformation recorded by the lacustrine sediments increases upwards through the sequence; from localised smallscale, normal faulting (northeast to southwest-trending) near the base, to more pervasive folding, thrusting and normal and reverse faulting higher in the sequence. These structures yield an overall north to northwest-directed sense of movement. Reverse faults that are developed within the upper part of the lacustrine sequence also deform the base of the overlying diamicton (Fig. 2). These faults are lined with laminated, normally graded fine-grained sand and silt that was deposited by water flowing along these structures. 


\subsection{Micromorphology}

The micromorphology of the glaciolacustrine sediments exposed at Raitts Burn has been described in detail by Phillips and Auton (2000) and is, therefore, only summarised here. Three orientated large format thin sections (S98555; S98557; S98556) taken at different levels within Unit II (Fig. 2) reveal a systematic change in the style and intensity of deformation upward through the sequence, confirming macroscopic field observations. Present throughout is a locally well-developed, bedding-parallel plasmic fabric (S1) which is deformed by a range of later structures, including kink bands (dextral sense of off-set), normal microfaults and small-scale shears. Near to the base of Unit II (S98555; see fig. 3 Phillips and Auton, 2000), bedding (S0) and S1 are off-set by two, steeply inclined clay-lined normal faults. Faulting also resulted in localised drag folding and brecciation of sediments in the immediate footwall and hanging-wall, with the tip of one of the faults terminating in a jigsaw-like breccia. The clay-lining to the faults possesses a well-developed plasmic fabric orientated parallel to the wall of the fault. This clay-lining is brecciated, indicating that at least one further phase of movement occurred along the faults.

Higher within Unit II (S98557; see Fig. 2), deformation resulted in reverse faulting. This was preceded by a phase of soft-sediment deformation accompanied by localised liquefaction and water-escape (Fig. 3). Sand-filled hydrofractures, which deform the laminated clay and silt in the lower part of the thin section, contain angular fragments of clay preserving earlier developed S1 fabric, kinks and shears. Soft-sediment deformation led to the formation of a convolute lamination and complex disharmonic folds within a bed of laminated silt and sand in the middle of the thin section (Fig. 3). Weakly laminated sand, in the upper part of the thin section, is deformed by a complex reverse fault, comprising an anastomosing network of discrete shear planes (north to northwest-directed sense of movement), enclosing lenticular fragments of laminated clay and silt (Fig. 3). There is no evidence of injection of fluidised sand along the fault, which clearly truncates the earlier developed soft-sediment deformation structures. Consequently, faulting post-dated liquefaction and its associated soft-sediment deformation ( $c f$. Phillips and Auton, 2000). 
Sample S98556 includes the boundary between the most intensely deformed part of Unit II and overlying diamicton of Unit III (see Fig. 2). The laminated silts and clays are deformed by a range of both ductile and brittle structures, including upright to recumbent folds, thrusts, normal and reverse microfaults (see fig. 6 of Phillips and Auton, 2000). Both the orientation of the thrusts and asymmetry of the folds record a northwest-directed sense of movement, with thrusting resulting in imbrication of the laminated silts and clays. The intensity of faulting increases towards the contact with the overlying diamicton. This contact is irregular, with 'flame-like' apophyses of plastically deformed silt and clay extending upwards into the diamicton. It is also offset by reverse faults, with the sandy matrix of the diamicton injected downward along these structures. Planar, lattice-like (lattisepic) and circular (skelsepic) fabrics are heterogeneously developed within the diamicton, reflecting the variation in clay content of the matrix.

\subsection{Interpretation}

The microstructures present in the Raitts Burn sediments show that the style of deformation changes upwards through the sequence associated with an increase in its intensity and complexity. The relationships between the various microstructures were interpreted by Phillips and Auton (2000) in terms of a polyphase deformation history (Fig. 4). At all stratigraphic levels within glaciolacustrine sediments, the earliest phase of deformation (D1) led to the development of the bedding-parallel S1 fabric within the clay laminae. Phillips and Auton (2000) suggested that this pervasive fabric developed in response to initial compaction/loading by overriding ice. This early fabric was subsequently deformed by kink bands and ductile shears, assigned to D2 (Fig. 4). The effects of D2 are not recognised in the upper part of the sequence, probably due to the complete destruction of the early structures by intense subsequent deformation at this level.

At the base of the sequence, the D1 and D2 structures are off-set by clay-lined normal (extensional) faults which are, therefore, D3 in age (Fig. 4). The presence of claylinings show that faults were open, allowing water to flow along them. The jigsawlike brecciation at the tip of one of the faults is thought to have formed in response to the flow of overpressured subglacial groundwater through the sediments (cf. Boulton and Caban, 1995); probably recording a marked increase in pore-water pressure 
during D3. Further evidence for an increase in pore-water pressure during D3 is provided by hydrofracturing of the more cohesive clays and accompanying liquefaction and soft-sediment deformation of sand and silt interbeds. The marked contrast in style of deformation shown by the clay-silt and sand laminae is directly related to sediment composition and the pore water pressure. The reverse faulting (designated as D4), in the middle part of the sequence, post-dates soft-sediment deformation and liquefaction (Fig. 4). It indicates an increase in the effective stress of the sediments after D3, due to a decrease in pore-water pressure in response to dewatering.

The most intense deformation occurs at the top of the glaciolacustrine sequence immediately below the diamicton. The resultant folding and thrusting, as well as normal and reverse faulting are assigned to D4 (Fig. 4) (cf. Phillips and Auton, 2000). All of these structures record a consistent north to northwest-directed sense of shear during D4. Initial ductile folding was followed by more brittle thrusting. The geometry of the array of normal and reverse faults associated with the thrusts is consistent with them having formed as Riedel shears (Passchier and Trouw, 1996). The thrusts and reverse faults propagated upwards through the glaciolacustrine sediments to deform the base of the newly deposited diamicton.

Phillips and Auton (2000) concluded that the D1 to D4 structures developed during a single progressive deformation event and that its intensity increased with time. D1 to D3 were attributed a subglacial origin, resulting from wet-based ice over-riding finegrained sediments, deposited in a proglacial lake. D4 records shearing which resulted from northerly directed ice-push during deposition of overlying morainic sediments.

\subsection{Coire Mhic-sith, Drumochter}

Coire Mhic-sith [NN 655 745] is a deeply incised, fault-guided valley located northeast of Dalnaspidal Lodge, near the Drumochter Pass col (Fig. 1) on the margin of the Gaick Plateau. As at Raitts Burn, the Coire Mhic-sith site preserves a sequence of fine-grained glaciolacustrine sediments which have been overridden by ice during a minor readvance. Sissons $(1974,1980)$ and Sissons et al., (1973) concluded that ice occupied the whole of Coire Mhic-sith during the Loch Lomond Stadial, flowing towards the southwest from an ice cap located on the Gaick Plateau to the northeast. 
However, no unequivocal evidence has been found in support of Loch Lomond Stadial ice flowing into the valley from the Gaick Plateau. Furthermore, the presence of glaciolacustrine deposits at the bottom of Coire Mhic-sith and a glacial spillway linking with a tributary valley of Edendon Water to the southeast, suggest that the Coire Mhic-sith valley was occupied by a lake ponded by ice to the southwest (see fig. 53 of Lucas and Merritt, 2004). The sense of movement indicated by the deformation structures preserved in the lacustrine sediments in Coire Mhic-sith clearly indicate that they were deformed during a minor readvance, when westerly sourced ice re-occupied the lower reaches of the valley (Lukas and Merritt, 2004), though the age of the readvance has yet to be established (see Benn and Ballantyne, 2005).

The Coire Mhic-sith sequence is shown in Fig. 5. A unit of silt and fine-grained micaceous sand (Unit I, Fig. 5), containing evidence of loading and sand ball development, occurs at the base of the sequence. It is overlain by a fining upward sequence of rhythmically laminated, glaciolacustrine clays, silts and very fine-grained sands (Unit II, Fig. 5). The top of Unit II is composed of extremely compact silt and clay, which is intensely deformed. The intensity of this deformation increases upwards towards the base of the overlying diamicton (Unit III, Fig. 5), in a manner similar to that seen at Raitts Burn. In the lower part of this deformed zone, the sedimentary lamination is folded and thrusted. The gently to moderately inclined asymmetrical folds and thrusts both record a consistent easterly directed sense of displacement. Although ductile folding is present, brittle faulting predominates. Immediately below the diamicton, the clay laminae are boudinaged into small rafts, that are included within a homogenous matrix of silt and sand. This, as at Raitts Burn, is again indicative of liquefaction and water escape. At Coire Mhic-sith, however, the deformed glaciolacustrine deposits are immediately overlain by a much harder, compact diamicton (Unit III, Fig 5), which is in turn overlain by a clast-supported cobble gravel (Unit IV, Fig. 5).

\subsection{Micromorphology}

Analysis of the deformed sediments at Coire Mhic-sith has confirmed that there is a systematic change in the style and intensity of deformation upward through the sequence. In thin section (N4127; N4128; N4129), these finely laminated 
glaciolacustrine sediments are seen to be composed of fine-grained sand, silt and clay (Fig. 6). As at Raitts Burn, the earliest deformation structure present throughout the sequence is a bedding-parallel (S1) plasmic fabric which is modified by all the other deformation structures. Although these later structures include ductile folds, deformation was predominantly brittle in nature and dominated by faulting. In the least deformed part of Unit II (N4127; see Fig. 5), bedding and S1 are off-set by a conjugate set of low-angle to moderately dipping reverse faults (Fig. 6a). The faults are marked by a narrow band of clay possessing a moderate to well-developed planar (unistrial) plasmic fabric (S2 in age). Open asymmetrical, monoclinal folds are locally developed within the hanging walls of these faults (Fig. 6a). In general, the folds and conjugate faults indicate an overall easterly directed sense of shear, suggesting that they developed during the same deformation event.

Sample N4128 is from slightly higher within Unit II (see Fig. 5). In thin section the laminated silts and clays are deformed by a prominent zone of thrusting, as well as by a number of westerly dipping reverse faults (Fig. 6b). These faults all record an easterly directed sense of movement, consistent with glacier ice advancing from the west. The clay-rich sediments at the bottom of the thin section are repeated by an anastomosing network of subhorizontal thrusts, defining a c. $2 \mathrm{~cm}$ wide zone of imbrication (Fig. 6b). Graded bedding preserved within the individual thrust slices indicates that the sediments were translated eastwards, but not overturned, during thrusting. Along the thrust planes, S1 is deformed to form an asymmetrical S-C fabric geometry (see Passchier and Trouw, 1996) which records a sinistral sense of shear, again consistent with an easterly directed sense of ice-movement. In the upper part of sample N4128, bedding is deformed by prominent reverse faults (Fig. 6b), with associated micro-faulting in their hanging walls. A layer of clean sand at the top of the sample has been partially homogenised, and contains angular, broken fragments of laminated silt and clay (Fig. 6b). A narrow fault zone can be traced into the homogenised sand. Sand has also been injected downwards along the fault, leading to brecciation within the immediate footwall (Fig. 6b). These microtextural relationships are consistent with the liquefaction and remobilisation of the sand having post-dated faulting. 
Sample N4129 (Fig. 7) was taken from the most intensely deformed part of the sequence, immediately below the diamicton (see Fig. 5). The upper part of the sample is highly deformed and composed of variably sheared and boudinaged fragments of laminated silt and clay within a relatively homogenous matrix of silt and very finegrained sand (Fig. 7). Locally the clay laminae are cut into a number of elongate, asymmetrical boudins. A moderately well-developed S1 plasmic fabric preserved within these clay boudins is deformed into an asymmetrical S-C-like fabric. Both the shape of the boudins and S-C-like plasmic fabric record a sinistral, easterly directed sense of shear. A similar sense of shear is also obtained from the asymmetry of the lamination preserved in the least deformed parts of the thin section (Fig. 7).

The highly sheared sediments at the top of sample N4129 are dissected by a number of gently easterly dipping extensional normal faults. These are lined by thin seams of silt and very fine-grained sand. The easterly directed sense of movement on the faults is comparable to similar structures developed within samples N4127 and N4128. This suggests that faulting at all levels within Unit II occurred during the same deformation event.

The lower part of the N4129 is composed of fragmented laminated sand, silt and silty clay, cut by a network of sand-filled veins or hydrofractures (Fig. 7). The fluidised clean sand which fills these veins is homogenous and contains small, randomly orientated fragments (rafts) of silt and clay. In general, however, the bedding can be traced between the individual fragments (see Fig. 7), indicating that there has been very little rotation and/or transport of these rafts. The laminated sediments which make up these fragments are themselves deformed by a number of normal and reverse microfaults. The fluidised sand has been injected along the larger of these faults, again indicating liquefaction and remobilisation of the sand post-dated initial faulting. The style of deformation and relative timing of liquefaction present in sample N4129 is comparable to that seen at the top of N4128.

\subsection{Interpretation}

The relationships between the various microstructures present within the deformed glaciolacustrine sediments exposed at Coire Mhic-sith can be shown to record a polyphase history of deformation (Fig. 8). Although the features include ductile folds, 
deformation within these sediments is predominantly brittle in nature. At all levels, the earliest phase of deformation (D1) led to the development of the bedding-parallel $\mathrm{S} 1$ fabric within the clay laminae. As in the Raitts Burn sequence, it is likely that this fabric developed in response to initial compaction and dewatering of the sediments or loading induced by an overriding glacier. Bedding and S1 are then deformed by both normal and reverse faults, which are, therefore, D2 in age (Fig. 8).

The sense of displacement recorded by the D2 thrusts, and by the normal and reverse faults (N4127; N4128) are all consistent with an easterly directed sense of ice-push. A similar sense of shear is recorded by folds developed within the hanging walls of the low-angle reverse faults, which is consistent with all of the folding and faulting having occurred during the same D2 deformation event. Sedimentary structures (e.g. graded bedding) clearly demonstrate that the sequence is the right way-up, indicating that D2 thrusting and folding did not result in the overturning and/or significant tectonic thickening of the sequence.

As at Raitts Burn, there is an observed increase in the intensity of deformation upwards through the Coire Mhic-sith sequence, with most intense deformation (represented by the top of sample N4129) occurring immediately below the overlying diamicton. Kinematic indicators (S-C-fabrics, asymmetry of the clay-silt boudins, sense of displacement on low-angle normal faults) present within these highly deformed silts and clays again record an easterly directed sense of shear; consistent with D2 in the underlying less deformed sediments (Fig. 8). Immediately below the highly deformed silts and clays (represented by the top of sample N4128 and bottom of sample N4129), the laminated sediments are cut by a network of diffuse, sandfilled veins and hydrofractures (Figs. 6b and 7). Liquefied sand also occurs along the earlier formed D2 faults, with the injection of this clean sand locally resulting in the brecciation of the laminated sediments in the immediate footwall of these structures. These relationships suggest that both compressional and extensional faulting had ceased, and that liquefaction and remobilisation of the sand post-dated D2 (see Fig. 8). The faults appear to have acted as fluid pathways aiding water-escape. Although liquefaction and water-escape occurred after brittle deformation, the rise in pore-water pressure leading to liquefaction occurred later, in response to a marked increase in overburden pressure induced by the overriding ice. 


\section{Proglacially deformed glaciolacustrine and distal deltaic sediments}

\subsection{Glen Luibeg, Cairngorm Mountains}

The deeply incised valley of Glen Luibeg [NH 017 937] is located on the southern margin of the Cairngorm Mountains (Fig. 1). During the Devensian glaciation these mountains formed an area of selective linear erosion (Sugden, 1968; Rea, 1998; Hall and Glasser, 2003), where a plateau ice field fed radial outlet glaciers that exploited zones of structural weakness in the underlying metasedimentary and granitic bedrock. During the last Glacial Maximum (c. 22 ka B.P.), these outlet glaciers were confluent with ice flowing eastward from a major accumulation area in the Western Highlands (Barrow et al., 1913; Brazier et al., 1996, 1998). During the latter stages of downwasting and retreat of the Main Late Devensian ice sheet, Glen Luibeg was occupied by a lake, impounded by ice occupying the lower reaches of the glen (Golledge, 2003). Meltwater carrying sediment from the glacier that dammed the lake, fed an ice-contact delta that prograded northwards.

Sediment accumulated in the ice-dammed lake to produce a thick sequence of laminated sands and silts with rare clays, interbedded with subaqueous debris-flow diamictons (see fig. 2 of Golledge, 2003). The lower part of the sequence at the Glen Luibeg [NH 017 937] site comprises a thick ( $>5 \mathrm{~m}$ ) massive matrix-supported diamicton, which is immediately overlain by much thinner $(0.5 \mathrm{~m})$ diamicton, containing thin beds and lenses of coarse sand (Units I and II, Fig. 9). Golledge (2003) interpreted both of these over-consolidated diamictons as being subglacial in origin, having been deposited by northerly retreating ice. This glacier occupied the glen prior to the formation of the lake, which was dammed by ice that impinged into the valley from the south. The diamictons are overlain by a thick unit of laminated silts and fine sands, with minor clay laminae (Unit III, Fig. 9). These fine-grained sediments are thought to record deposition within both the distal parts of the delta and on the lake bed. The upper $1 \mathrm{~m}$ of Unit III is highly deformed and disrupted. Open folds and faults are common, and the sedimentary lamination is locally streaked out and boudinaged. The glaciolacustrine and deltaic sediments are overlain by a thin gravelly diamicton (Unit IV, Fig. 9) which grades upwards into a unit of poorly bedded sand and silt (Unit V Fig. 9). The diamicton is interpreted as a debris flow 
with the overlying sands partially reworking the top of this deposit (Golledge, 2003). The clast-rich, sandy diamicton at the top of the sequence (Unit VI, Fig. 9) is thought to have been deposited as a subaqueous debris flow.

\subsection{Micromorphology}

Two orientated samples (N5080; N5081) were taken from the deformed upper part of Unit II (see Fig. 9). Sample N5080 was orientated parallel to the main direction of ice movement determined for Glen Luibeg area by Golledge (2003), with sample N5081 approximately orthogonal to it. This allowed the microstructures to be examined in 3D.

In thin section, the glaciolacustrine sediments are composed of finely laminated sand, silt and clay (Fig. 10). The sand and silt laminae are normally graded, indicating that although deformed, the sediments are the right way up. A bedding-parallel fabric, defined by the preferred shape alignment of detrital micas, is developed within the sands. In the adjacent clay laminae, a weakly developed S1 plasmic fabric occurs parallel to the sedimentary lamination. In both samples (N5080; N5081), the lamination and S1 foliation are deformed by several sets of microfaults, indicating that the imposition of the bedding-parallel fabric pre-dated faulting and is D1 in age.

Although open folding was observed at outcrop, in thin section small-scale folding is limited to very localised drag folds, with deformation being dominated by brittle faults (Fig. 10). Microstructures associated with proglacial deformation are best developed within sample N5080, where four sets of faults have been recognised (Fig. 10a): (1) sub-horizontal to gently south-dipping thrusts; (2) gently to moderately south-dipping reverse faults; (3) a set of gently to moderately north-dipping normal faults; and (4) a small number of steeply dipping normal and reverse faults and associated shear bands. The sense of displacement on the thrusts and gently to moderately dipping normal and reverse faults, are consistent with an overall sense of displacement towards the north. In general, the faults belonging to sets 2 and 3 terminate at, or link into the thrust faults (set 1) (Fig. 10a). However, in the upper part of sample N5080, a prominent normal fault (set 3) cuts through and off-sets the tip of a thrust (Fig. 10a). The tip of this thrust is marked by asymmetrical, disharmonic microfolds which are dissected by a number of small-scale reverse faults. 
Individual fault planes (normal and reverse) are diffuse in nature and marked by a narrow band of realigned detrital micas or thin seam of very fine-grained silty sand. On a number of the normal faults (set 3) the silty sand and silt linings are graded, indicating that these extensional structures were open, allowing water flow along the fault plane. Thrusts are preferentially developed within the clay-rich part of the sequence and are defined by a poorly to moderately developed planar (unistrial) plasmic fabric. In the central part of sample N5080, a number of closely spaced thrusts have resulted in the imbrication of the clay-rich laminated sediments (Fig. 10a). Bedding within the individual thrust slices has been tilted and is weakly arcuate in form. This asymmetry of the lamination yields a sinistral sense of shear, consistent with northerly directed thrusting.

Although a similar range of structures are developed in both N5080 and N5081 there is a clear difference in the apparent intensity of deformation recorded by each sample (compare Figs. 10a and 10b). The most intense deformation is recorded in sample N5080 which was aligned parallel to the main direction of inferred ice movement. Sample N5081 is orientated at right angles to N5080, parallel to the strike of the main fault sets identified in the latter (see Fig 11a). Consequently, in sample N5081 the majority of the faults occur parallel, or at a low-angle to bedding. Their lower angle of apparent dip and apparent amount of displacement is seen to be due to the plane of orientation of the section. The main planes of displacement in sample N5081 can be correlated with the thrusts (set 1) and normal faults (set 3) present in sample N5080 (Fig. 11a). As in sample N5080, the thrusts in N5081 result in the imbrication of the clay-rich horizons, as well as minor folding (Fig. 10b). Both the thrusts and normal faults record an easterly directed sense of movement and are cross-cut by irregular sand-filled veins (Fig. 10b); the latter clearly post-date faulting. A small number of moderate to steeply, easterly dipping normal and reverse faults were also observed in the latter sample.

\subsection{Interpretation}

The microstructures within the laminated sediments exposed in Glen Luibeg indicate that proglacial deformation was dominated by brittle faulting. All of the fault sets displace bedding and the variably developed bedding-parallel fabric (S1). This clearly 
indicates that the imposition of S1 pre-dated faulting, and that the faults are consequently D2 in age (Fig. 12). In the sandy laminae, this S1 fabric is defined by shape-aligned detrital micas and is probably primarily of sedimentary origin. It is likely that the bedding-parallel S1 plasmic fabric present within the adjacent clay laminae may also have pre-dated proglacial deformation, and developed during deposition and/or in response to loading during compaction and initial dewatering of the sedimentary pile.

The correlation that can be made between the faults present within samples N5080 and N5081, allows the construction of a 3D model (Fig. 11a) of the structures present. The main structural elements are the subhorizontal thrusts, moderately south-dipping reverse faults and north-dipping normal faults. The geometry of these structures is consistent with them having developed together as Riedel shears (Fig. 11b) during the same D2 deformation event. The cross-cutting relationship shown between a normal fault ( $\mathrm{R}$ shear, Fig. 11b) and one of the thrusts (Y shear, Fig. 11b) suggests that deformation was progressive in nature. The micromorphological evidence also indicates that thrusting was preferentially partitioned into the more clay-rich parts of the sequence. Detachments developed along these relatively weaker clay-rich horizons would have accommodated the initial shortening of the sedimentary pile during initial ice-push. As deformation continued, the earlier formed thrusts (T1, Fig. 11a) may have been abandoned, as continued compression was accommodated by displacement along a number of larger, more active thrust planes (T2, Fig. 11a). These more prominent thrust systems developed within the thicker, more laterally extensive clay-rich horizons. Further shortening and compression of the sedimentary pile, at a later stage of D2, was accommodated by shortening in the hanging walls of the main thrust systems leading to normal and reverse faulting. These later faults locally deform earlier developed structures resulting in the observed cross-cutting relationships displayed between the various sets of faults (see Fig. 10).

The sense of displacement on the various sets of faults present in the thin sections from Glen Luibeg are consistent with an overall northerly directed sense of shear during deformation. The minor easterly directed off-set recorded by the faults in sample N5081, indicates that the ice-push leading to proglacial deformation was slightly east of north; probably towards the north-northeast. This direction is 
consistent with the minor re-advance of ice into Glen Luibeg from the south, postulated by Golledge (2003).

\section{Glacially overridden sands and subglacial diamicton}

\subsection{Plumpe Farm, near Gretna}

The exposure at Plumpe Farm [NY 3344 6813] is situated to the east of the Scottish Border at Gretna (BGS, 2006). The site is located within gently undulating low-lying drumlinised ground close to where Trotter (1922) first recognised evidence of a significant southward readvance of Scottish ice into the Solway Lowlands during the Late Devensian glaciation. Further evidence for this readvance was found in the Carlisle area, to the south, where the so-called 'tripartite sequence' was established and subsequently correlated across northwest England (Trotter and Hollingworth, 1932). Evidence for this readvance was subsequently questioned by Pennington (1970), Evans and Arthurton (1973) and Thomas (1985). However, recent work (Merritt and Auton, 2000; Huddart, 2002 and references therein) supports the existence of a 'Scottish Readvance' and speculative correlations have been made with Heinrich Event 1 of the northern hemisphere (McCabe et al., 1998). All of these recent studies suggest that, during the 'Scottish Readvance', glaciofluvial and glaciolacustrine sediments laid down in the Solway Lowlands during the initial retreat of the last Late Devensian ice sheet were over-ridden by ice from the Southern Uplands.

Generally east-west orientated drumlins in the Gretna area record an overall eastward ice-flow direction across this till-covered part of the Solway lowlands. The exposure at Plumpe Farm is orientated at right-angles to this ice-flow direction. The exposed sequence is shown in Fig. 13 and probably constitutes only the upper most part of a locally thick, extensive Quaternary succession developed on permeable PermoTriassic sandstone. A thick deposit of laminated glaciofluvial or glaciolacustrine sand, silt and gravel (Plumpe Sand and Gravel Formation) (Units I and II, Fig. 13) is overlain by diamicton, the Plumpe Bridge Till (Unit III, Fig. 13) (BGS, 2006). The medium- to fine-grained sands and silts are graded and locally possess a ripple crosslamination. In the surrounding area these sediments are underlain by a stiff, reddish brown clayey till referred to as the Chapelknowe Till Formation. The upper part of 
Unit II is very hard and compact (Fig. 13) and appears to grade into the base of the overlying diamicton. The silts and sands of Unit II are over-consolidated, consistent with them having been overridden by ice. However, no obvious macroscopic deformation structures (folds, faults) were observed at outcrop in Unit II or in the less consolidated sands and silts of Unit I.

\subsection{Micromorphology}

Four samples (N2840; N2841; N2842; N2843) were collected across the boundary between the laminated silts and sands (Units I and II), and overlying diamicton (Unit III) (see Fig. 13). The samples were orientated parallel to the easterly regional iceflow direction.

In thin section (N2840; N2841) the sediments from the Plumpe Sand and Gravel Formation are composed of laminated fine-grained sand, silt and clay (Fig. 14a). Some of the thicker sand laminae are normally graded and preserve a low-angle cross lamination. These sediments are essentially undeformed. Deformation, where present, is restricted to minor soft-sediment deformation (flame structures, disharmonic folds, water-escape conduits) and associated liquefaction (Fig. 14a). Localised faulting and rare recumbent folding have also been observed.

The samples (N2842; N2843) from the base of the Plumpe Bridge Till (Fig. 13) are composed of a stratified, poorly sorted, sandy diamicton containing layers of highly disrupted laminated silt and clay (Fig. 14b). The clay-rich layers within the till are lithologically similar to those within the underlying laminated sediments. The stratification within the diamicton becomes less pronounced and more diffuse upwards away from its base.

Sample N2842 was taken to intersect the gradational boundary between the till and the underlying glaciofluvial/glaciolacustrine sediments. In detail, this boundary zone was found to comprise alternating layers of laminated silt and clay and sandy diamicton (Fig. 14b). Internally the silt and clay layers are variably deformed and disrupted. In the least deformed layers, the lamination is contorted by small-scale disharmonic folds, recumbent rootless folds and flame structures. These soft-sediment deformation structures are cross-cut by thin veinlets and lenticles of clay cutan. The 
silt laminae are variably homogenised, with liquefaction leading to the overprinting of earlier developed structures. In the more highly deformed layer, broken angular fragments of laminated clay occur within a homogenised silty or silty clay matrix. These disrupted layers also contain rounded to elongate till pebbles (Type 1 till pebbles, van der Meer 1993) (Figs. 14c to e). The till pebbles are similar in composition to the adjacent layers of diamicton and may be attached to them by a thin tail.

The edges of the diamicton layers are highly irregular in form (Fig. 14b). Locally they are contorted into open, cuspate folds and narrow, elongate flames. These flames are filled by variably homogenised silt and/or clay cutan. Individual bands of diamicton, as well as the margins of thicker layers, may be composed of rounded to elongate till pebbles within a matrix of clay cutan (Figs. 14b to e). This clay matrix possesses a well-developed plasmic fabric (Fig. 14d) which wraps around the till pebbles. However, apart from locally being embayed against neighbouring more rigid rock fragments, the till pebbles are essentially undeformed. The resultant pebble-rich diamicton has a matrix- to clast-supported, 'globular' texture (Figs. 14b and e).

\subsection{Interpretation}

Thin sections of the fine sands, silts and clays from the Plumpe Sand and Gravel Formation confirm field observations that these sediments are largely undeformed. Deformation, where present, is restricted to possible compaction, minor folding and soft-sediment contortions due to loading. Although the Plumpe Sand and Gravel Formation has been over-ridden by ice, the absence of significant glacitectonic deformation suggests that conditions at the ice-sediment interface were such as to impede the transmission of shear into these finely laminated sediments.

The boundary between the Plumpe Sand and Gravel Formation and overlying Plumpe Bridge Till is gradational over a few 10's of centimetres. Microstructures present within the stratified base of the till, such as disharmonic folds and flame structures, coupled with the liquefaction and homogenisation of the silty laminae are consistent with the sediment having had a high water content during the deposition and deformation of this diamicton. 
The lack of pervasive deformation in the glacially overridden laminated sands and silts at Plumpe Farm may, at least in part, be a result of the regional palaeogeography at the time of the Scottish Readvance. During the Readvance, glacier ice from the Southern Uplands flowed over the flat-lying glaciofluvial/glaciolacustrine sediments, encountering a number of ice-marginal lakes ponded against high ground to the east (Trotter, 1929; Hollingworth, 1932). The water-saturated nature of these sediments aided movement of the ice, which locally would have occurred on a water lubricated surface. This lubricated surface dramatically reduced the amount of shear translated into the underlying sediments of the Plumpe Sand and Gravel Formation. Any displacement would have been focused into this water-rich zone leading to the observed disharmonic folding and soft-sediment deformation being confined within the stratified base of the Plumpe Bridge Till.

The layers rich in till pebbles within the diamicton are thought to have developed during the deposition of the Plumpe Bridge Till. Van der Meer (1993) concluded that till pebbles develop in response to rotational movement (simple shear) during subglacial deformation (also see van der Meer, 1994; Hiemstra and van der Meer, 1997). The model proposed by van der Meer (1993) requires initial fracturing of the till followed by rotation and rounding of the pebbles (see fig. 6 of Hiemstra and van der Meer, 1997). The microtextures developed within the Plumpe Bridge Till indicate that, in this case, the diamicton was apparently water saturated at the time of till pebble formation. The layers rich in till pebbles within the stratified base of this diamicton possess a matrix-supported texture; the matrix being composed of a clay cutan (Figs. 14b to e). Initial 'fragmentation' of the diamicton may have occurred in response to turbulent flow within the water-saturated sediment (cf. Phillips, 2006; Evans et al., 2006). This would have also aided in the mixing and incorporation of the underlying laminated fine-grained sediments into the base of the diamicton. Liquefied silt and clay derived from these fine-grained sediments would have been remobilised and injected into diamicton. During this process, clay would have been deposited within the interstices between the till pebbles, coating these grains with a layer of cutan. The distinctive 'globular' appearance of the till pebble layers is thought to have developed in response to the mixing of these water-saturated sediments with the diamicton during the deposition of the Plumpe Bridge Till; an interpretation supported by the gradational nature of its base. 


\section{Subglacial and proglacial deformed deltaic gravels, sands and silts, and associated diamictons}

\subsection{Drumbeg Quarry, near Drymen}

Drumbeg Quarry [NN 479 877] lies to the southeast of the village of Drymen east of Loch Lomond in central Scotland (Fig. 1), within the limit of the Loch Lomond Readvance marked by its terminal moraine (Rose, 1981). The quarry cuts through one of a series of ridges formed by coalesced ice-contact subaqueous fans/deltas that prograded into Lake Blane during the recession of the eastern margin of the Loch Lomond glacier lobe from its readvance limit (see fig. 1 of Phillips et al., 2002). The sequence of deltaic sands and gravels (Fig. 15), and proximal subaqueous outwash gravels (Benn and Evans, 1996) were locally deformed during the active retreat of the Loch Lomond glacier.

Phillips et al. (2002) provided macroscopic evidence that these sediments had undergone a polyphase deformation history interspersed with periods of erosion and deposition. The earliest deformation event (D1) was driven by the northeasterly readvance of the Loch Lomond lobe into the ice-contact slope of the fan/delta. This proglacial D1 deformation event, is restricted to the lower part of the sequence now exposed at Drumbeg Quarry (Unit I, Fig. 15). It resulted in tilting of bedding and tectonic thickening of the sequence by folding (F1) and thrusting. In the mid- to outerparts of the fan/delta, however, sedimentation apparently continued uninterrupted during D1 deformation. As the ice retreated, the fan-delta was re-established, leading to a period of erosion of the lower parts of the succession, followed by deposition of a sequence of proximal sands and gravels (Unit II, Fig. 15) upon these underlying polydeformed sediments.

A second phase of readvance of the Loch Lomond ice-lobe resulted in ductile shearing and disruption of this proximal sedimentary sequence (Phillips et al., 2002). This northeast-directed, subglacial deformation event (D2) accompanied the deposition of a carapace of diamicton (2-3 m thick) (Unit III, Fig. 15) and affected a greater part of the fan-delta complex than D1. Folding and boudinage during D2 lead to the disruption of the originally well-bedded sediments and eventual disaggregation 
and homogenisation of the sand and gravel beds. Deformation within the sand, silty sand and clay-rich lenses is highly heterogeneous. In the most intensely deformed units, the sedimentary lamination is transposed by a well-developed, finely banded fabric. This apparently intense deformation is in marked contrast to that recorded by the adjacent sand lenses, in which primary sedimentary structures (lamination, grading, cross-bedding) are often preserved. Elsewhere, D2 resulted in soft-sediment deformation, accompanied by liquefaction and water escape. An anastomosing network of ductile shear zones formed during D2, locally tectonically excised parts of the underlying sequence. One of these shear zone forms the contact between this D2 deformed sequence and the overlying diamicton (Fig. 15). Phillips et al. (2002) interpreted a southwest-dipping banding within this 'high strain zone' as a glacitectonic fabric. However, no obvious macroscopic kinematic indicators were recognised within it.

The subsequent retreat of the Loch Lomond ice-lobe, from the overridden part of the ice-contact delta, was accompanied by erosion and truncation of all the earlier developed deformation structures and partial removal of the diamicton. The underlying deformed sequence was unconformably overlain by sands and gravels (Unit IV, Fig. 15) as the fan-delta complex was re-established. Deposition of the locally channellised deltaic sequence was apparently terminated by the deposition of a thin diamicton which caps the sequence exposed in Drumbeg Quarry.

\subsection{Micromorphology: proglacially deformed sediments}

Two orientated samples (N3772; N3773) were collected from the limbs of the F1 folds within the proglacially deformed part of the sequence (see Fig. 15). In thin section the interlaminated silt, silty clay and sand are deformed by a well-developed domainal crenulation cleavage to transposition fabric (Fig. 16). This fabric occurs axial planar to the macroscopic F1 folds and is, therefore, S1 in age. The microstructural relationships developed within the domainal S1 crenulation cleavage are comparable to those present within deformed metamorphic rocks (see Bell and Rubenach, 1983; Vernon, 1989; Passchier and Trouw, 1996). The sedimentary lamination (S0) is preserved within the lower strain areas, or domains, of the S1 fabric, where it is deformed by tight to isoclinal crenulation-style microfolds (Fig. 16). The sense of shear recorded by these crenulations is consistent with them having 
developed in response to layer-parallel flexural-slip on the limb of the larger, macroscopic F1 fold.

In the clay-rich laminae, a fine-scale foliation is defined by narrow clay-rich shears which possess a weakly to moderately developed planar (unistrial) plasmic fabric. This plasmic fabric occurs axial planar to the crenulations and is, therefore, S1 in age. In the more intensely deformed areas, the sedimentary lamination has been transposed into a new tectonic banding or foliation composed of alternating clay- and silt-rich foliae. This foliation is parallel to the crenulation cleavage (Fig. 16b) and is, therefore, also S1 in age. The apparently lower strain domains within the S1 crenulation cleavage contain lenses or patches of massive to weakly laminated, clean sand (Fig. 16). These sand lenses occur parallel to $S 1$, but are locally observed cross-cutting this foliation (Fig. 16). The lenses and patches of clean sand which cross-cut S1, correspond to the macroscopic sand-filled water-escape features described by Phillips et al. (2002). These features occur axial planar to the F1 folds, with liquefied sand apparently have been injected along the S1 crenulation cleavage.

In sample N3773 the S1 crenulation cleavage is off-set by a northeast-directed thrust and reverse faults (Fig. 16b). The faults are marked by a thin layer or seam of clayey silt, suggesting that they may have controlled water-escape either during, or after D1.

\subsection{Micromorphology: subglacial deformation}

Samples of the most highly disrupted sands and silts were collected from the subglacially deformed part of the Drumbeg sequence (N3771; N3775) and the overlying diamicton (N3770; N3769) (see Fig. 15).

In thin section (N3771; N3775) the subglacially deformed sands possesses a distinctive, streaked-out, mottled appearance and are composed of irregular to elongate patches of silty sand and clay. The original sediment was composed of interlaminated fine-grained sand, silt and clay. The boundaries between the sandy and more clay-rich areas are highly irregular, lobate to locally flame-like, consistent with these sediments have been strongly modified and disrupted due to deformation and accompanying liquefaction. The patches of finely laminated silt and clay are deformed by convolute to disharmonic folds. These clay-rich sediments locally grade 
into irregular patches of clay cutan. The lamination within the silt-clay patches is either a primary sedimentary feature, or in some instances is of secondary in origin and formed during liquefaction and remobilisation of the sediment.

The sandy patches possess an open to moderately packed, 'cement'- to grainsupported texture. The 'cement' is composed of a clay cutan which possess a welldeveloped plasmic fabric that wraps around the included sand grains. The overall texture of these sands suggest that this 'cement' was formed when the sediment was in a highly dilated, fluidised state. Clay cutan also fills irregular veinlets and wispy to flame-like lenticles which cross-cut the sands. In sample N3775, these clay-filled features form an anastomosing network of micro-scale flow zones which developed during the dewatering of the sands.

The till that caps the subglacially deformed sequence is composed of a poorly sorted, matrix supported, sandy diamicton (N3770) containing pebbles of sandstone, basalt and metamorphic rocks (Fig.17). The diamicton is little deformed, with only a very weakly developed plasmic fabric. The very low clay content and sandy nature of the diamicton matrix, however, would have restricted plasmic fabric development during subglacial deposition and deformation. A lack of any obvious deformation structures within the diamicton at Drumbeg was also noted by Evans and Hiemstra (2005) who equated till deposition with a process of incremental thickening in an oscillating submarginal setting.

Sample N3770 (Fig. 17) is from the base of the diamicton and includes part of the shear zone developed at the contact with the underlying sands and gravels. In thin section the macroscopic foliation developed within this shear zone, is defined by alternating bands or layers of laminated silt, silty clay and sand. Sedimentary structures are, in general, absent within the silts and clays, which is consistent with the banding/lamination being glacitectonic in origin. This interpretation is supported by the presence of a variably developed layer-parallel plasmic fabric (S2) within the clay-rich bands. However, when examined at higher magnification a number of the silty laminae are seen to be reverse-graded, suggesting that they are, at least in part, water-lain. The fine-scale banding and layer-parallel plasmic fabric are deformed by disharmonic folds, flame structures and diffuse shears, indicative of soft-sediment 
deformation. Some of the silt laminae have also been homogenised, with liquefaction possibly contemporaneous with soft-sediment deformation. The disrupted clay-rich layer immediately below the diamicton possesses a well-developed lattisepic plasmic fabric and is deformed by narrow shear bands. These shear bands define a variably developed extensional crenulation cleavage (ECC) or SC-fabric. The sense of shear recorded by this fabric is uncertain due to later disruption.

The layering within the shear zone is cross-cut by a number of sand-filled hydrofractures (lower part of N3770, Fig. 17). At the base, these water-escape features are connected to a layer of clean sand which contains angular to subangular fragments of silty clay that are lithologically similar to the adjacent banded finegrained sediments. The sand-filled hydrofractures also penetrate the base of the overlying diamicton. Immediately below the diamicton the sand-filled water-escape conduits spread laterally and are associated with a zone of fragmented/brecciated silt and clay (Fig. 17). Elongate, broken 'rafts' of silt and clay also occur at the base of the diamicton.

\subsection{Interpretation}

The micromorphological analysis confirms the field observations of Phillips et al. (2002) that there is a marked contrast in the style of proglacial D1 and subglacial D2 deformation recorded by the glacigenic sediments at Drumbeg Quarry (see Fig. 18). The predominantly sandy sediments deformed during D1 have undergone folding and thrusting (Fig. 18). F1 folding was accompanied by the imposition of an axial planar, domainal S1 crenulation to transposition fabric within the finer grained units (Figs. 16 and 18). The morphology of this fabric is similar to crenulation cleavages developed within polydeformed metamorphic rocks (Bell and Rubenach, 1983; Vernon, 1989; Passchier and Trouw, 1996) with crenulation-style folding of bedding being preserved within lower strain domains. Sand-filled water-escape conduits occur parallel to, and locally cross-cut S1. In detail, these sand-filled features developed along the lower strain domains of the S1 cleavage (Fig. 16). This microtextural relationship indicates that S1 locally controlled the sites of water-escape and that dewatering occurred during D1. 
In contrast to the subglacial D1 event, microstructures developed during the later subglacial D2 deformation of the overlying ice-proximal sands and gravels, are consistent with the soft-sediment deformation. The composition of the sediments affected by D1 and D2 are similar, so any differences in the style of deformation are probably related to water content and pore water pressure at the time of deformation. Both D1 and D2 were caused by the advance of the Loch Lomond ice-lobe northeastwards into Lake Blane. Consequently, it is likely during both readvance phases, the deltaic sediments were water saturated. Differences in water content and pore pressure during D1 and D2 may, therefore, have been affected by the setting of these deformation events. For instance, during proglacial D1 deformation the relatively high porosity and permeability of these unconsolidated sands would have initially allowed water to escape, keeping the effected pore-water pressure relatively low. However, tectonic thickening of the sedimentary pile during subglacial deformation (D1), would have resulted in the consolidation of the sediments. This may have led to a reduction in permeability and an increase in pore-water pressure. The result would have been the localised liquefaction and fluidisation of the sands during the later stages of D1. The presence of thin silt and clay interbeds also formed temporary barriers, locally impeding water-escape. The progressive development of the domainal S1 cleavage within these clayey sediments, however, provided an ideal fluid pathway allowing trapped pore-water to escape.

During subglacial D2 deformation, the ice-proximal sands and gravels were completely overridden by ice, leading to deposition of a carapace of diamicton covering these water-saturated sediments. The diamicton would have formed a relatively impermeable cap, retarding water-escape and causing an increase in porewater pressure. Loading, exerted by the overriding ice, would have added to this pressure increase. Consequently, subglacial D2 deformation of these water saturated sediments was characterised by liquefaction and soft-sediment deformation. The large-scale disruption of this part of the Drumbeg glacigenic sequence is therefore interpreted as having been largely due to elevated water pressures and liquefaction, rather than high shear strains produced by the overriding ice. Evans and Hiemstra (2005) suggested that till deposition at Drumbeg was incremental and associated with an seasonally oscillating ice margin. These seasonal oscillations in the ice margin 
would have accompanied a fluctuation in pore water content and pressure within the underlying sedimentary sequence.

The shear zones, recognised by Phillips et al. (2002), which locally tectonically excised parts of the already disrupted sequence, developed at a later stage of D2. At the time, dewatering of the sedimentary pile would have allowed an increase in the amount of shear transmitted into the glacier bed, where it was partitioned into discrete shear zones. One of these shear zones is developed along the contact between the iceproximal sands and gravels, and the overlying diamicton (Fig. 15). Microstructures developed within this shear zone include banded foliation, layer-parallel plasmic fabric in the clays; narrow shear bands defining ECC or SC fabrics and disharmonic folds; as well as sand-filled hydrofractures that post-date the imposition of the main foliation. However, a number of the more silty bands within this apparently highly deformed zone are reverse-graded or homogenised due to localised liquefaction. The presence of soft-sediment deformation and liquefaction features within this shear zone suggest that pore-water pressure continued to fluctuate and that the shear zones presented preferential sites for fluid pathways to develop allowing water to escape. The injection of fluidised silt and sand into these actively deforming zones may also have acted as a lubricant aiding displacement. The increase in pore-water pressure during injection of this fluidised material into the shear zones could also have acted as a hydraulic jack, resulting in the decoupling of the diamicton from the underlying sediments. One potential effect of this decoupling would be the rafting and imbrication of the diamicton during the later stages of D2 subglacial deformation.

\section{Discussion}

Systematic micromorphological analysis represents a powerful tool for investigating the often complex deformation histories recorded by sequence of glacigenic sediments. The detailed examination of the range of microstructures developed at Raitts Burn, Coire Mhic-sith, Glen Luibeg, Plumpe Farm and Drumbeg Quarry has provided information regarding the nature of subglacial and/or proglacial deformation recorded by these sediments, beyond that can be gleaned from macroscopic investigations of the exposures in the field alone. A number of general conclusions can be made: 
- A similar range of macro- and microstructures (folds, faults, hydrofractures, crenulation cleavages, plasmic fabrics) has been observed in both subglacially (Raitts Burn, Coire Mhic-sith, Drumbeg) and proglacially (Glen Luibeg, Drumbeg) deformed sediments (Table 1). However, the results of the Scottish studies suggest that soft-sediment deformation structures and features resulting from liquefaction and homogenisation may be more widely developed within subglacially deformed sediments;

- Similar progressive polyphase deformation histories have been recognised in the deformed sequences exposed at Raitts Burn, Coire Mhic-sith, Glen Luibeg and Drumbeg (see Figs. 4, 8, 12 and 18). In general, this involves a phase of ductile folding and thrusting, in response to initial ice-push, followed by continued thrusting and associated brittle faulting during further shortening within the sedimentary pile. The geometry of the array of normal and reverse faults associated with the thrusts are consistent with them having formed as Riedel shears (Passchier and Trouw, 1996);

- At Raitts Burn deformation structures (thrusts, reverse faults) developed within the underlying sediments propagated upwards through these glaciolacustrine sediments to deform the base of the recently deposited diamicton. This relationship was not observed/preserved at any of the other sites.

- The composition of the sediment plays an important role in the style and relative intensity of deformation. The relatively weak, finely laminated clayrich glaciolacustrine sediments at Raitts Burn, Coire Mhic-sith and Glen Luibeg preserve a range of fine-scale microstructures including folds and faults. At Coire Mhic-sith and Glen Luibeg the clay-rich parts of the sequence formed a focus for thrusting, with, at least the early stages, of both subglacial and proglacial deformation (respectively) being partitioned into these weaker layers. In contrast, the range of microstructures present within the sandy sequence at Drumbeg is more restricted in nature, with deformation being characterised by macroscopic folding and thrusting; 
- The partitioning of deformation was recognised at all sites and seen to be strongly lithological controlled. For example, at Glen Luibeg early thrusting was concentrated within the clay units;

- Plasmic fabrics are only developed within clay-rich sediments. The intensity of these fabrics varies with respect to the clay mineral content of the sediment and, therefore, should not be used as a general indicator of the comparative intensity of deformation;

- At the sites examined the water content and pore-water pressure in the sediments increased during both subglacial and proglacial deformation. This increase can occur at several stages during the progressive deformation and results in varying degrees of liquefaction, hydrofracturing and homogenisation within the sedimentary pile;

- The earliest sedimentary (bedding, S0) and deformation (S1) features can be preserved in low strain zones even within the most intensely deformed parts of the glacigenic sequences;

- On the microscopic scale, liquefaction and remobilisation mainly affected coarse silt- and sand-grade sediments at Raitts Burn, Coire Mhic-sith and Drumbeg. This process locally led to the overprinting of earlier deformation structures and homogenisation of the sediment.

At all the sites, the earliest deformation (D1) recorded by the sediments resulted in the imposition of a bedding-parallel S1 plasmic fabric within the clays. This beddingparallel fabric can be recognised locally at all stratigraphic levels within the sequences examined and is deformed by the other microstructures. Consequently, the development of the bedding-parallel S1 fabric occurred very early in the deformation history. At Raitts Burn, Phillips and Auton (2000) suggested that this pervasive fabric developed in response to initial compaction/loading by the overriding glacier. However, at Glen Luibeg, the glaciolacustrine to distal deltaic sediments have 
undergone proglacial deformation rather than subglacial deformation and were not overridden. It is possible that in this case, S1 developed in response to initial beddingparallel shear prior to thrusting (see Fig. 15). Alternatively, the development of a bedding-parallel plasmic fabric can be unrelated to either proglacial or subglacial deformation and simply records loading and compaction associated with initial dewatering of the sedimentary sequence during deposition (e.g. Plumpe Farm).

The subglacially deformed sediments exposed at both Raitts Burn and Coire Mhicsith record a progressive increase in the intensity and complexity of deformation upwards through the sequence towards the base of an overlying till. This is consistent with the deforming bed model proposed by Boulton et al. (1974), Boulton and Hindmarsh (1978) and Boulton and Jones (1979) to explain the movement of glaciers. It is possible that the preservation of a systematic change in the style and intensity of deformation upwards through the sequence may be a characteristic feature of subglacial deformation. However, the glacially overridden succession present at Plumpe Farm does not show a comparable increase in the intensity of deformation towards the base of the till. Micromorphological analysis and field observations together demonstrate that the fine-grained sediments of the Plumpe Sand and Gravel Formation are essentially undeformed. Microstructures present within the stratified base of the Plumpe Bridge Till are consistent with this diamicton having had a high water content at the time of deposition and deformation. This probably aided the mixing of the underlying fine-grained clayey sediments into the till and the formation of till pebble layers within the stratified base of the diamicton.

During the Scottish Readvance, the flat-lying, ice-marginal glaciofluvial and glaciolacustrine sediments seen at Plumpe Farm were thought to have been saturated in water, aiding the advance of the ice across the Solway basin. In contrast to the upland sites which are confined to small narrow basins cut in resistant, relatively impermeable bedrock, the Plumpe Farm site is located in a broad, flat-lying basin close to sea-level and with a regionally high water table, resulting in long lived wet conditions. The development of a water-lubricated surface at the base of the ice dramatically reduced the amount of shear translated into the underlying sediments. Displacement focused into this water-rich zone, leading to the observed disharmonic folding and soft-sediment deformation. The lack of any obvious deformation within 
the Plumpe Bridge Till suggests that this water-rich zone was maintained throughout the readvance and till deposition. This may have been due to poorly drained, clay-rich nature of the sediments below the ice.

At Raitts Burn, Phillips and Auton (2000) suggested that the early stages of ice movement across an ice-dammed lake also occurred on a water-lubricated surface. The result was that only a minor amount of shear was translated into the underlying sediments during the early stages (D1 to D3) of deformation (see Fig. 6). A subsequent fall in pore-water pressure, following a phase of hydrofracturing, sediment fluidisation and water-escape (D3; Fig. 6), led to an increase in both the cohesive strength of the sediments and amount of shear translated into the bed of the glacier. The result was the observed increase in the intensity of deformation (D4; Fig. 6) in the upper part of the glaciolacustrine sequence. The continued presence (Plumpe Farm) or demise (Raitts Burn) of a water-rich zone at the base of the glacier as it overrides a sequence of water-saturated sediments must be controlled by: (a) the permeability of the sediments within its bed; and (b) the ability of water to drain from these sediments at the front of the advancing glacier. The confined, poorly drained nature of subglacial environments, such as that at Plumbe Farm, may therefore lead to the development of water-saturated detachments within the sediment pile effectively 'switching off' pervasive subglacial deformation and potentially the decoupling of the glacier from its bed.

Microtextural evidence from the subglacially deformed sediments at Raitts Burn, and Coire Mhic-sith, and proglacially deformed sediments in the lower part of the sequence exposed at Drumbeg Quarry reveal that the pore-water pressure and content of the sediments fluctuated during deformation at each site. At Raitts Burn the claylined normal (D3) faults (Fig. 3), sand- and clay-filled hydrofractures (Figs. 4 and 5), soft-sediment deformation structures (convolute lamination, disharmonic folds; Fig. 5), and the accompanying liquefaction of the sandy layers, all record an increase in the pore-water pressure during deformation (D1 to D3; Fig. 6). Brecciation associated with the hydrofractures and jigsaw-like breccia at the tip of one of the normal faults record the flow of overpressured subglacial groundwater through the sediments (cf. Boulton and Caban, 1995; Phillips and Auton, 2000). Brecciation of the clays during liquefaction of interbedded sand laminae was also observed at Coire Mhic-sith. The 
highly deformed silts and clays immediately below the till, are invaded by a network of sand-filled veins and hydrofractures (Fig. 10). During liquefaction, sand was injected along the earlier formed (D2) faults, the latter initially acting as fluid pathways aiding water-escape. However, pore-water pressure apparently continued to rise until it exceeded the cohesive strength of the adjacent clays leading to hydrofracturing and associated brecciation. A similar structural control on the pattern of water-escape was locally provided by the domainal S1 cleavage developed axial planar to the NE-verging F1 folds associated with proglacial deformation of the deltaic sediments exposed at Drumbeg Quarry. Sand-filled water-escape conduits were injected along the lower strain domains of this cleavage.

Results of these studies indicate that although structures associated with soft-sediment deformation and liquefaction are not indicative of subglacial deformation they may be very widespread in glacial overridden sedimentary sequences. High pore-water pressures and contents leading to water saturated conditions within the sedimentary pile are more likely to develop within confined, poorly drained subglacial to submarginal settings. Whereas, in proglacial settings, although drainage may be temporarily impeded, hydrofracturing and water-escape will effectively prevent such conditions developing. The rise in pore-water pressure during subglacial deformation at both Raitts Burn and Coire Mhic-sith is most likely to have been due to the increase in overburden pressure induced by overriding ice. At Drumbeg, the proglacial setting of the earlier (D1) phase of deformation and sandy nature of the sediments means that, at least initially, they would have been able to dewater relatively easily. The tectonic thickening of the sedimentary pile during deformation, however, led to consolidation of the sediments and an increase in pore-water pressure. The local presence of thin silt and clay interbeds also formed temporary impermeable barriers impeding water-escape. The progressive development of the S1 fabric during deformation provided a fluid pathway, allowing trapped pore-water to escape.

Field and micromorphological observations demonstrate that there is a marked contrast in the style of proglacial (D1) and subglacial (D2) deformation recorded by the ice-proximal sediments exposed at Drumbeg Quarry. This difference in style can be related to the water content of the sediments at the time of deformation. The subaqueous depositional environment of Lake Blane meant that the Drumbeg deposits 
would have been water-saturated during both D1 and D2 readvances of the Loch Lomond glacier. As noted above, the proglacial setting of D1 and sandy nature of the sediments would have aided dewatering during deformation. The composition of the sediments affected by D1 and D2 are similar (i.e. sand-rich). Consequently, the observed differences in the style of deformation are thought to be related to differences between the water content and pore-water pressure during each deformation episode. In contrast to D1, macro- and microstructures developed during D2 are consistent with soft-sediment deformation and liquefaction of water-saturated sediments. The deposition of an impermeable layer of till at the base of the overriding ice during D2 would have retarded drainage and water-escape. The resultant increase in pore-water pressure within these already water-rich sediments, coupled with the load exerted by the overriding ice, led to the observed large-scale disruption. Anastomosing shear zones, tectonically excise parts of this already disrupted sequence. These shear zones developed at a later stage of D2 when the sedimentary pile had begun to dewater, possibly reflecting renewed drainage from the front of the glacier. Microstructures developed within the shear zones indicate that they acted as fluid pathways, showing that pore-water pressure continued to fluctuate. The injection of pulses of fluidised sediment into these actively deforming zones would have acted as a lubricant, aiding displacement and possibly resulting in the decoupling of the diamicton from the underlying sediments. The shear zones would have acted as fluid pathways aiding the dewatering of the sedimentary pile.

\section{Subglacial versus Proglacial deformation?}

It is clear from the above discussion that micromorphological analysis is an important tool when attempting to unravel the detailed deformation history recorded by deformed glacigenic sequences. Care must be taken, however, to integrate the micromorphological data with wider palaeoenvironmental observations (notably on the direction of ice advance and retreat). The results of this study show that a similar range of deformation structures can be developed in both proglacial and subglacial glacitectonic environments (Table 1). The structures, which include a variety of folds, faults, plasmic fabrics and crenulation cleavages, are developed on a range of scales (macroscopic to microscopic) with their inter-relationships allowing the progressive and/or polyphase nature of the deformation history to be established (Menzies 2000, 
van der Wateren et al., 2000; Phillips and Auton, 2000, Phillips et al., 2002; this study). However, rather than the glacitectonic setting representing the sole controlling factor, the composition and water content of the sediment has been found, in most cases, to be the dominant influence on the style and apparent intensity of deformation.

Soft-sediment deformation, hydrofracturing, liquefaction and homogenisation can occur in both subglacially and proglacially deformed sequences (Golledge, 2002; Rijsdijk et al., 1999; Baroni and Fasano, 2006). However, the Scottish examples suggest that, although not indicative of subglacial deformation, structures equated with high pore-water pressure and/or content may be more widely/pervasively developed in subglacially deformed sediments. In both environments pore-water pressure builds up during deformation and may lead to repeated phases/episodes of liquefaction, hydrofracturing and water-escape (e.g. Raitts Burn, Coire Mhic-sith, Drumbeg). Earlier developed structures, such as faults, folds and cleavages, may control the sites of later water-escape (e.g. F1 folds at Drumbeg), with these early structures locally being overprinted as a result of liquefaction and homogenisation.

The confined nature of the subglacial environment may allow water-saturated conditions to be maintained resulting relatively wide spread liquefaction and disruption of the sediment pile (e.g. Unit II at Drumbeg), and/or the development of water lubricated detachments within the sedimentary pile (e.g. Plumpe Farm, high strain zones at Drumbeg). At Plumbe Farm, the water-saturated detachment developed at the base of the till appears to have accommodated most if not all the shear imposed by the overriding Southern Uplands glacier ice. The partitioning of deformation into this water-lubricated detachment would have resulted in a dramatic lowering of the amount of shear transmitted into the underlying sediments protecting it from deformation. The development of such detachments, however, may occur at a deeper level within the sediment pile or even within the underlying bedrock (see Bluemle and Clayton 1984; Truffer et al., 2000; Truffer and Harrison, 2006), with the detached sediments being transported, relatively undeformed, within the hanging-wall of these structures. However, the development of a water-saturated detachment is not indicative of subglacial deformation as similar features have been noted within the shear zones developed at the base of mass flow deposits (Lachniet et al., 1999; Lachniet et al., 2001; Phillips, 2006). 


\section{Conclusions}

The study of the structures in subglacially and proglacially deformed sediments has been providing important information on the signature of each type of glacier-induced deformation. Micromorphological studies carried out on a number of sites in a variety of geological and topographical settings throughout Scotland have demonstrated that a similar range of both macroscopic and microstructures can be developed in both glacitectonic environments. Consequently, no unequivocal discrimination can be made between the subglacially and proglacially deformed sediments based upon this type of evidence alone. However, the Scottish studies suggest that soft-sediment deformation and structures related to liquefaction and water-escape may be more widely developed within the subglacial rather than in the proglacial environment. A multidisciplinary approach, involving sedimentological, geomorphological and structural field observations, combined with micromorphological analysis, is needed to unravel the full glacitectonic history and depositional environment of most deformed glacigenic sedimentary sequences. Examination of the microstructures (folds, faults, thrusts, crenulations, hydrofractures and plasmic fabrics) may aid in understanding the often polyphase deformation histories recorded by these sequences. Furthermore, kinematic indicators, such as the asymmetry of shear fabrics and folds, as well as the sense of off-set on faults, can not only be used to reconstruct palaeo-ice movement directions but to test palaeoenvironmental reconstructions derived from more traditional 'field based' observations.

The multidisciplinary studies of these Scottish Quaternary sites have also shown that sediment composition, water content and pore-water pressure are important controlling factors influencing the style and apparent intensity of deformation recorded. Changes in pore-water content and pressure during both proglacial and subglacial deformation can lead to liquefaction and hydrofracturing, with early formed structures locally controlling the pattern of water escape. Liquefaction can also lead to homogenisation of the sediments, overprinting of earlier deformation structures. Beds or zones of fluidised sediment commonly form highly lubricated detachments within the sedimentary pile, partitioning the deformation and resulting in a marked reduction in the amount of shear transmitted to underlying units. 
Although micromorphological analysis is a powerful tool in glacial deformation studies where possible it should be used as part of a multidisciplinary approach, involving sedimentological, geomorphological and structural field observations, when attempting to unravel the glacitectonic history and depositional environment of deformed glacigenic sedimentary sequences.

\section{Acknowledgements}

The work forms part of the British Geological Survey's Geology and Landscape Northern Britain Programme. David Oates is acknowledged for his expertise in making thin sections of even the most poorly consolidated sediments. Jaap van der Meer, Tom Bradwell and Jez Everest are thanked for their comments and discussion of an earlier draft of this manuscript. Jon Lee, John Hiemstra and Kenneth Rijsdijk are acknowledged for their constructive reviews. This paper is published with the permission of the Executive Director of the British Geological Survey (NERC).

\section{References}

Aber, J.S., Croot, D.G., Fenton, M.M. 1989. Glaciotectonic Landforms and Structures. Kluwer, Dordrecht.

Baroni, C., Fasano, F. 2006. Micromorphological evidence of warm-based glacier deposition from the Ricker Hills Tillite (Victoria Land, Antarctica). Quaternary Science Reviews. 25, 976-992.

Barrow, G., Hinxman, L.W., Cunningham Craig, E.H. 1913. The geology of Upper Strathspey, Gaick and the Forest of Atholl. Memoirs of the Geological Survey of Scotland. HMSO. Edinburgh.

Benn, D.I., Evans, D.J.A. 1993. Glacimarine deltaic deposition and ice-marginal tectonics: the 'Loch Don Sand Moraine', Isle of Mull, Scotland. Journal of Quaternary Science. 8, 279-291.

Benn, D.I., Evans, D.J.A. 1996. The interpretation and classification of subglacially deformed materials. Quaternary Science Reviews. 15, 23-52. 
Benn, D.I., Evans, D.J.A. 1998. Glaciers and Glaciation. Arnold, London.

Benn, D.I., Ballantyne, C.K. 2005. Palaeoclimatic reconstruction from Loch Lomond Readvance glaciers in the West Drumochter Hills, Scotland. Journal of Quaternary Science. 20, 577-592.

Bell, T.H., Rubenach, M.J. 1983. Sequential porphyroblast growth and crenulation cleavage development during progressive deformation. Tectonophysics. 92, 171 - 94.

Berthelsen, A. 1978. The methodology or kineto-stratigraphy as applied to glacial geology. Bulletin of the Geological Survey of Denmark. 27, 25-38.

Bluemle, J.P., Clayton, L. 1984. Large-scale glacial thrusting and related processes in North Dakota. Boreas. 13, 279-299.

British Geological Survey. 2006. Solway East. Scotland Special Sheet. Superficial Deposits and Simplified Bedrock. 1:50,000 Geology Series. British Geological Survey, Keyworth, Nottingham.

Boulton G.S., Dent D.L., Morris E.M. 1974. Subglacial shearing and crushing, and the role of water pressures in tills from south-east Iceland. Geografiska Annaler. 56A, 135-145.

Boulton G.S., Hindmarsh R.C.A. 1987. Sediment deformation beneath glaciers: rheology and geological consequences. Journal of Geophysical Research. 92, 90599082.

Boulton G.S., Jones A.S. 1979. Stability of temperate ice sheets resting on beds of deformable sediment. Journal of Glaciology. 24, 29-43.

Boulton, G.S., Caban, P. 1995. Groundwater flow beneath ice sheets: Part II - its impact on glacier tectonic structures and moraine formation. Quaternary Science Reviews. 14, 563-587. 
Boulton, G.S., Dobbie, K.E., Zatsepin, S. 2001. Sediment deformation beneath glaciers and its coupling to the subglacial hydraulic system. Quaternary International. 86, 3-28.

Brazier, V., Gordon, J.E., Kirkbride, M.P., Sugden. D.E. 1996. The Late Devensian ice sheet and glaciers in the Cairngorm Mountains. In Glasser, N.F., Bennett, M.R. (eds). The Quaternary of the Cairngorms: Field Guide. Quaternary Research Association Field Guide, p28-53.

Brazier, V., Kirkbride, M.P., Gordon, J.E. 1998. Active ice sheet deglaciation and icedammed lakes in the northern Cairngorm Mountains, Scotland. Boreas, 27, 297-310.

Carr, S.J., Holmes, R., van der Meer, J.J.M., Rose, J. 2006. The last glacial maximum in the North Sea basin: Micromorphological evidence of extensive glaciation. Journal of Quaternary Science. 21, 131-153.

Carr, S.J., Haflidason, H., Sejrup, H.P. 2000. Micromorphological evidence supporting late Weichselian glaciation of the northern North Sea. Boreas. 29, 315328.

Choukroune, P., Gapais, D., Merle, O. 1987. Shear criteria and structural symmetry. Journal of Structural Geology. 9, 525-530.

Eyles, N.E., Eyles, C.H., Miall, A.D. 1983. Lithofacies types and vertical profile models; an alternative approach to the description and environmental interpretation of glacial diamict and diamictite sequences. Sedimentology. 30, 393-410.

Evans, W.B., Arthurton, R.S. 1973. North-west England. In Mitchell, G.F, Penny, L.F, Shotton, F.W., West, R.G. (eds). A correlation of Quaternary deposits in the British Isles. Geological Society of London Special Report. 4, 28-36. 
Evans, D.J.A., Rea, B.R., Benn, D.I. 1999. Subglacial deformation and bedrock plucking in areas of hard bedrock. Glacial Geology and Geomorphology. http:/ggg.qub.ac.uk/ggg/papers/full/1998/rp04/html.

Evans, D.J.A., Hiemstra, J.F. 2005. Till deposition by glacier submarginal, incremental thickening. Earth Surface Processes and Landforms. 30, 1633-1662.

Evans, D.J.A., Phillips, E.R., Hiemstra, J.F., Auton, C.A. 2006. Subglacial till: formation, sedimentary characteristics and classification. Earth Science Reviews. 78 (1-2), 115-176.

Golledge, N.R. 2002. Glacitectonic deformation of proglacial lake sediments in the Cairngorm Mountains. Scottish Journal of Geology, 38, 127-136.

Golledge, N.R. 2003. A former ice-dammed lake in Glen Luibeg, Cairngorm Mountains, Scotland. Quaternary Newsletter, 101, 13-24.

Hall, A.M., Glasser, N.F. 2003: Reconstructing the basal thermal regime of an ice stream in a landscape of selective linear erosion: Glen Avon, Cairngorm Mountains, Scotland. Boreas. 32, 191-207.

Harris, C., Williams, G., Brabham, P., Eaton, G., McCarroll, D. 1997. Glaciotectonized Quaternary sediments at Dinas Dinlle, Gwynedd, North Wales and their bearing on the style of deglaciation in the eastern Irish Sea. Quaternary Science Reviews. 16, 109-127.

Hart, J., Rose, J. 2001. Approaches to the study of glacier bed deformation. Quaternary International. 86, 45-58.

Hiemstra, J.F., van der Meer, J.J.M. 1997. Pore-water controlled grain fracturing as an indicator for subglacial shearing in tills. Journal of Glaciology. 43, 446-454.

Hiemstra, J.F., Rijsdijk, K.F. 2003. Observing artificially induced strain: implications for subglacial deformation. Journal of Quaternary Science. 18, 373-383. 
Hiemstra, J.F., Rijsdijk, K.F., Evans, D.J.A., van der Meer, J.J.M. 2005. Integrated micro- and macro-scale analyses of Last Glacial maximum Irish Sea diamicts from Abermaw and Treath y Mwnt, Wales, UK. Boreas. 34, 61-74.

Khatwa, A., Tulaczyk, S. 2001. Microstructural interpretations of modern and Pleistocene subglacially deformed sediments: the relative role of parent material and subglacial processes. Journal of Quaternary Science. 16, 507-517.

Lachniet, M.S., Larson, G.J., Strasser, J.C., Lawson, D.E., Evenson, E.B. 1999. Microstructures of glacigenic sediment flow deposits, Matanuska Glacier, Alaska. In Mickleson, D.M., Attig, J.W. (eds). Glacial Processes Past and Present. Geological Society of America, Special Paper. 337, Boulder, CO.

Lachniet, M.S., Larson, G.J., Lawson, D.E. Evenson, E.B., Alley, R.B. 2001. Microstructures of sediment flow deposits and subglacial sediments: a comparison. Boreas. 30, 254-262.

Lukas, S. 2002. Geomorphological evidence for the pattern of deglaciation around the Drumochter Pass, Central Grampian Highlands, Scotland. Unpublished MSc thesis, Ruhr-University of Bochum, Germany, 115pp.

Lukas, S., Merritt, J.W. 2004. Evidence for former ice-damned lake in Corrie-Mhicsith. In Lukas, S., Merritt, J.W., Mitchell, W.A. (eds). The Quaternary of the Central Grampian Highlands: Field Guide. Quaternary Research Association.

McCabe, A.M., Knight, J., McCarron, S. 1998. Evidence for Heinrich event 1 in the British Isles. Journal of Quaternary Science. 13, 549-568.

McCarroll, D., Rijsdijk, K.F. 2003. deformational styles as a key for interpreting glacial depositional environments. Journal of Quaternary Science. 18, 473-489.

Menzies, M. 2000. Micromorphological analyses of microfabrics and microstructures indicative of deformation processes in glacial sediments. In Maltman, A.J., Hubbard, 
B., Hambrey, J.M. (eds). Deformation of Glacial Materials. Geological Society, London, Special Publications. 176, 279-292.

Menzies, J., van der Meer, J.J.M., Rose, J. 2006. Tills - as a glacial “tectomict”, its internal architecture, and the development of a "typing" method for till differentiation. Geomorphology. 75, 172-200.

Merritt, J.W., Auton, C.A. 2000. An outline of the lithostratigraphy and depositional history of Quaternary deposits in the Sellafield district, west Cumbria. Proceedings of the Yorkshire Geological Society. 53, 129-154.

Miall, A.D. 1978. Lithofacies types and vertical profile models in braided rivers: a summary. In Miall, A.D. (ed.). Fluvial Sedimentology. Canadian Society of Petroleum Geology Memoir. 5, 597-604.

Passchier, C.W., Trouw, R.A.J. 1996. Microtectonics. Springer.

Pedersen, S.A.S. 1993. The glaciodynamic event and glaciodynamic sequence. In Aber, J. S. (ed.). Glaciotectonics and Mapping Glacial Deposits. Canadian Plains Research Centre, University of Regina. 67-85.

Pennington, W. 1978. Quaternary Geology. In Moseley, F. (ed). The Geology of the Lake District. Yorkshire Geological Society Occasional Publication. 3, 207-225.

Phillips, E.R. 2006. Micromorphology of a debris flow deposit: evidence of basal shearing, hydrofracturing, liquefaction and rotational deformation during emplacement. Quaternary Science Reviews. 25, 720-738.

Phillips, E.R., Auton, C.A. 2000. Micromorphological evidence for polyphase deformation of glaciolacustrine sediments from Strathspey, Scotland. In Maltman, A.J. Hubbard, B., Hambrey, J.M. (eds). Deformation of Glacial Materials. Geological Society, London, Special Publications. 176, 279-292. 
Phillips, E.R., Evans, D.J.A., Auton, C.A. 2002. Polyphase deformation at an oscillating ice margin following the Loch Lomond Readvance, central Scotland, UK. Sedimentary Geology. 149, 157-182.

Rea, B.R. 1998: The Cairngorms - a landscape of selective linear erosion. Scottish Geographical Magazine. 114, 124-129.

Rijsdijk, K.F., Owen, G., Warren, W.P., McCarroll, D., van der Meer, J.J.M. 1999. Clastic dykes in over-consolidated tills: evidence for subglacial hydrofracturing at Killiney Bay, eastern Ireland. Sedimentary Geology. 129, 111-126.

Rose, J. 1981. Field guide to the Quaternary geology of the south eastern part of the Loch Lomond basin. Proceedings of the Geological Society of Glasgow. 122/123, $12-$ 28.

Sugden, D.E. 1968. The selectivity of glacial erosion in the Cairngorm Mountains, Scotland. Transactions of the Institute of British Geographers. 51, 201-219.

Sissons, J.B. 1974. A late glacial ice cap in the central Grampians, Scotland. Transactions of the Institute of British Geographers. 62, 95-114.

Sissons, J.B. 1980. Palaeoclimatic inferences from Loch Lomond Readvance glaciers. In Lowe, J.J., Gray, J.M., Robinson, J.E. (eds). Studies in the Late glacial of Northwest Europe. Pergamon Press, Oxford, 31-44.

Sissons, J.B., Lowe, J.J., Thompson, K.S.R., Walker, M.J.C. 1973. Loch Lomond Readvance in the Grampian Highlands of Scotland. Nature Physical Science. 244, 7577.

Thomas, G.S.P. 1985. The Quaternary of the northern Irish Sea basin. In Johnson, R.H. (ed). The geomorphology of North-west England. Manchester University Press, Manchester, 143-158. 
Trotter, F.M. 1922. Report from the Cumberland District. In Summary of Progress of the Geological Survey of Great Britain for 1921. 46-48.

Trotter, F.M., Hollingworth, S.E. 1932. The glacial sequence in the North of England. Geological Magazine. 69, 374-380.

Truffer, M., Harrison, W.D., Echelmeyer, K.A. 2000. Glacier motion dominated by processes deep in underlying till. Journal of Glaciology. 46, 213-221.

Truffer, M., Harrison, W.D. 2006. In situ measurements of till deformation and water pressure. Journal of Glaciology. 52, 175-182.

van Gijssel, K., 1987. A lithostratigraphic and glacitectonic reconstruction of the Lamstedt Moraine, Lower Saxony (FRG). In van der Meer, J.J.M. (ed.). Tills and Glacitectonics. A.A. Balkema, Rotterdam. 145-156.

van der Meer, J.J.M. 1987. Micromorphology of glacial sediments as a tool in distinguishing genetic varieties of till. In Kujansuu, R., Saarnisto, M (eds). INQUA Till Symposium, Finland 1985. Geological Survey of Finland, Special Paper 3, 77-89.

van der Meer, J.J.M. 1993. Microscopic evidence of subglacial deformation. Quaternary Science Reviews. 12, 553-587.

van der Meer, J.J.M., Laban, C. 1990. Micromorphology of some North Sea till samples, a pilot study. Journal of Quaternary Science. 5, 95-101.

van der Meer, J.J.M., Rabassa, J.O., Evenson, E.B. 1992. Micromorphological aspects of glaciolacustrine sediments in northern Patagonia, Argentina. Journal of Quaternary Science. 7, 31-44.

van der Meer, J.J.M., Verbers, A.L.L.M. 1994. The micromorphological character of the Ballycroneen Formation (Irish Sea Till): a first assessment. In Warren, Croot, (eds). Formation and Deformation of Glacial Deposits. Balkema, Rotterdam. 39-49. 
van der Meer, J.J.M., Kjaer, K., Krüger, J. 1999. Subglacial water escape structures and till structure, Sléttjökull, Iceland. Journal of Quaternary Science. 14, 191-415.

van der Meer, J.J.M., Menzies, J., Rose, J. 2003. Subglacial till: the deforming glacier bed. Quaternary Science Reviews. 22, 1659-1685.

van der Wateren, F.M. 1986. Structural geology and sedimentology of the Dammer Berge push moraine, FRG. In van der Meer, J.J.M. (ed.). Tills and Glacitectonics. A.A. Balkema, Rotterdam. 157-182.

van der Wateren, F.M. 1995. Process of glaciotectonism. In Menzies, J. (ed.). Glacial Environments. Modern Glacial Environments: Processes, Dynamics and Sediments. vol. 1. Butterworth-Heinemann, Oxford. 309-335.

van der Wateren, F.M., Kluiving, S.J., Bartek, L.R. 2000. Kinematic indicators of subglacial shearing. In Maltman, A.J., Hubbard, B., Hambrey, J.M. (eds). Deformation of Glacial Materials. Geological Society, London, Special Publications. 176, 259-291.

Vernon, R.H. 1989. Porphyroblast-matrix microstructural relationships: recent approaches and problems. In Daly and others. (eds). Evolution of metamorphic belts. Geological Society of London Special Publication. 43, 83-102.

Young, J.A.T. 1978. The landforms of the Upper Strathspey. Scottish Geographical Magazine. 94, 76-94.

\section{Figures}

Fig. 1. Map of Scotland showing the location of Raitts Burn (Strathspey), Glen Luibeg (Cairngorm Mountains), Coire Mhic-sith (Drumochter), Drumbeg Quarry (Drymen) and Plumpe Farm (Gretna) study areas.

Fig. 2. Simplified lithological log of the Quaternary deposits exposed at Raitts Burn (after Phillips and Auton, 2000). Photograph shows small-scale reverse fault cutting 
silt-clay rhythmites, top of Unit II; trowel $26 \mathrm{~cm}$ long. *Lithofacies codes after Miall (1978) and Eyles et al. (1983).

Fig. 3. Representative thin section of deformed laminated silt and clay overlain by sand exposed at Raitts Burn. Deformation structures include sand-filled hydrofractures and water escape conduits, soft-sediment deformation structures (disharmonic folds and convolute lamination) and a prominent reverse fault marked by lenses of sheared clay (sample S98557; middle of Unit II, Raitts Burn; see Fig. 2 for location of sample).

Fig. 4. Diagram summarising the relative age relationships (based upon microtextural evidence) and changes in the style of subglacial deformation within the Raitts Burn glaciolacustrine sequence (after Phillips and Auton, 2000).

Fig. 5. Simplified lithological log of the Quaternary deposits exposed at Coire Mhicsith, Drumochter. Photograph shows the laminated glaciolacustrine sediments (Unit II) overlain by diamicton (Unit III) and location of samples N4127, N4128 and N4129 relative to the boundary between these two lithological units. *Lithofacies codes after Miall (1978) and Eyles et al. (1983).

Fig. 6. Deformed laminated clay, silt and fine-grained sand exposed at Coire Mhicsith. (a) Well-developed low-angle reverse faults and thrusts in sample N4127 (base of Unit II). Minor folding and faulting occurs in the hanging walls of these structures; (b) Layer-parallel thrusting in sample N4128 (middle of Unit II) resulted localised imbrication and repetition of the very fine-grained sediments. Minor injection of fluidised sand occurred along the reverse faults deforming the laminated sand, silt and clay in the upper part of the sample (see Fig. 5 for location of samples).

Fig. 7. Highly deformed laminated clay and silt (top of Unit II) overlying variably disrupted and fragmented sand, silt and clay cut by a network of sand-filled hydrofractures (sample N4129; see Fig. 5 for location of sample). 
Fig. 8. Diagram summarising the relative age relationships (based upon microtextural evidence) and changes in the style of subglacial deformation within the Coire Mhicsith glaciolacustrine sequence.

Fig. 9. Simplified lithological log of the Quaternary deposits exposed at Glen Luibeg, Cairngorm Mountains. Photograph shows the increase in deformation upwards through the sequence of laminated deltaic (distal) to glaciolacustrine sediments (Unit III) and location of samples N5080 and N5081.

Fig. 10. Highly deformed laminated clay, silt and fine-grained sand (Unit III) exposed at Glen Luibeg. Deformation in both samples (N5080, N5081) is dominated by thrusting and low-angle normal faulting. Subhorizontal thrusts are preferentially developed within the clay-rich layers and resulted in small-scale imbrication and repetition of these fine-grained sediments: (a) Sample N5080 is orientated parallel to the main ice movement direction; (b) Sample N5081 is orientated orthogonal to the ice movement direction (see Fig. 10 for location of samples).

Fig. 11. (a) Block diagram showing the 3D geometry of the microstructures developed within the proglacially deformed sediments exposed at Glen Luibeg. (b) Diagram showing the characteristic geometry and sense of shear of the most common types of Riedel shears (labelled R, R', P and Y shears).

Fig. 12. Diagram summarising the relative age relationships (based upon microstructural evidence) of deformation structures developed during proglacial deformation of the Glen Luibeg distal deltaic/glaciolacustrine sequence.

Fig. 13. Simplified lithological log of the Quaternary deposits exposed at Plumpe Farm near Gretna. Photograph shows the laminated sands and silts and clays (Unit II) overlain by diamicton (Unit III). The location of samples N2840, N2841, N2842 and N2843 are also shown.

Fig. 14. (a) Laminated silt and clay (sample N2840, upper part of Unit I) with only locally developed soft-sediment deformation structures and minor thrust faults; (b) 
Stratified base of diamicton (sample N2842, base of Unit III) composed of alternating layers of clay-rich fine sediment and diamicton; (c) Detail of finely interlaminated diamicton and clay with complex, lobate to irregular boundaries between the individual laminae (plane polarised light); (d) Detail of finely interlaminated diamicton and clay. The clay-rich laminae are composed of highly birefringent clay cutan (crossed polarised light); (e) rounded to irregular till pebbles within a finegrained matrix composed of highly birefringent clay cutan (see Fig. 13 for location of samples).

Fig. 15. Photomosaic showing the main deformation structures and tectonostratigraphical units exposed at Drumbeg Quarry near Drymen (after Phillips et al., 2002). Also shown are the locations of samples N3769, N3770, N3771, N3772, N3773, N3774 and N3775 collected from both the proglacially and subglacially deformed parts of the sequence.

Fig. 16. (a) Laminated silt and fine-grained sand in sample N3772 (Unit I) deformed by a well-developed crenulation cleavage (S1). Bedding is locally transposed by this locally pervasive glacitectonic fabric; (b) The well-developed crenulation cleavage (S1) and associated microfolds in sample N3773 are off-set by a later, northeastdirected thrust and moderately dipping reverse faults. Bedding within these finely laminated sediments is locally transposed by the S1 glacitectonic fabric (see Fig. 15 for location of samples).

Fig. 17. Laminated silt and very fine-grained sand overlain by pebbly diamicton (sample N3770) containing sub-angular to rounded locally derived fragments of sandstone. The laminated fine-grained sediments represent the 'high strain zone' which forms the contact between the diamicton (Unit III) and underlying subglacially deformed sediments (Unit II) (see Fig. 15 for location of sample).

Fig 18. Diagram summarising the relative age relationships (based upon macro- and microstructural evidence) of structures developed during proglacial (D1) and subglacial (D2) deformation of the deltaic sequence exposed at Drumbeg Quarry.

\section{Tables}


Table 1. Summary of the range of deformation microstructures developed within the deformed glacigenic sediments exposed at Raitts Burn, Coire Mhic-Sith, Glen Luibeg, Plumpe Farm and Drumbeg Quarry, and their glacitectonic setting. $\sqrt{ }=$ well developed $\sqrt{ }=$ poorly developed/present. 


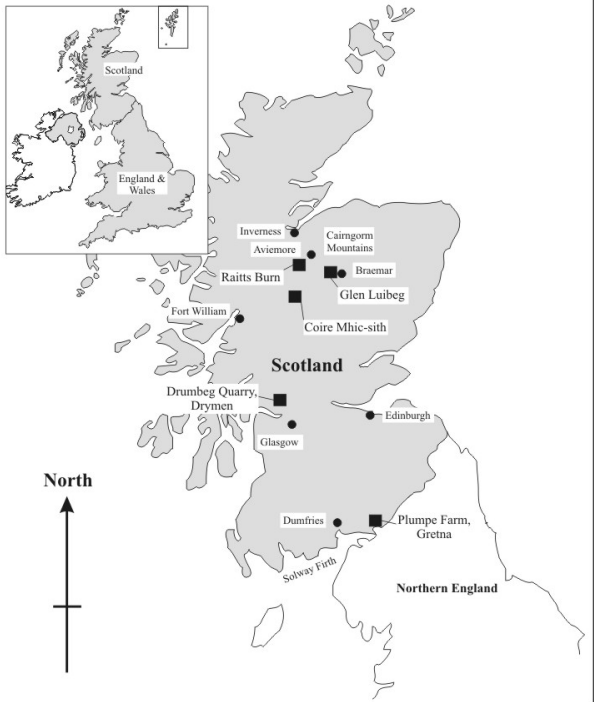

Fig. 1. 
Location: Raitts Burn, Strathspey

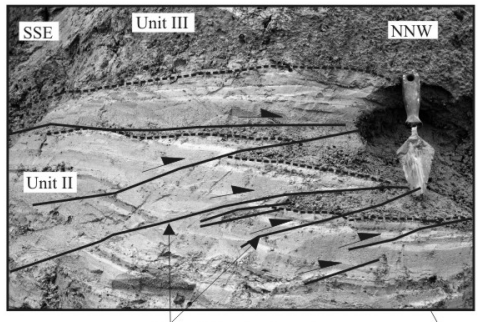

reverse faults deforming boundary between Unit II and III

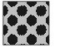

diamicton

sand, silt, clay

gravel metres

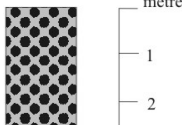

Description / Interpretation

UNIT III (Dms/Dem-Gms)

Clast supported sandy diamicton, passing laterally into poorly sorted matrix-rich gravel

Glacigenic deposit

UNIT II

(Fl/Fhd; minor Sm, Dms)

Sand-silt-clay rhythmites, minor interbedded diamictons and sands

Over-ridden glaciolacustrine sediment with brittle and soft-sediment deformation structures

\section{UNIT I (Gm)}

Matrix-rich, clast supported boulder and cobble gravel

Proglacial debris flow deposit

Fig. 2 


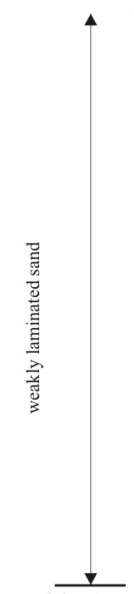

zone of shearing associated with reverse fault
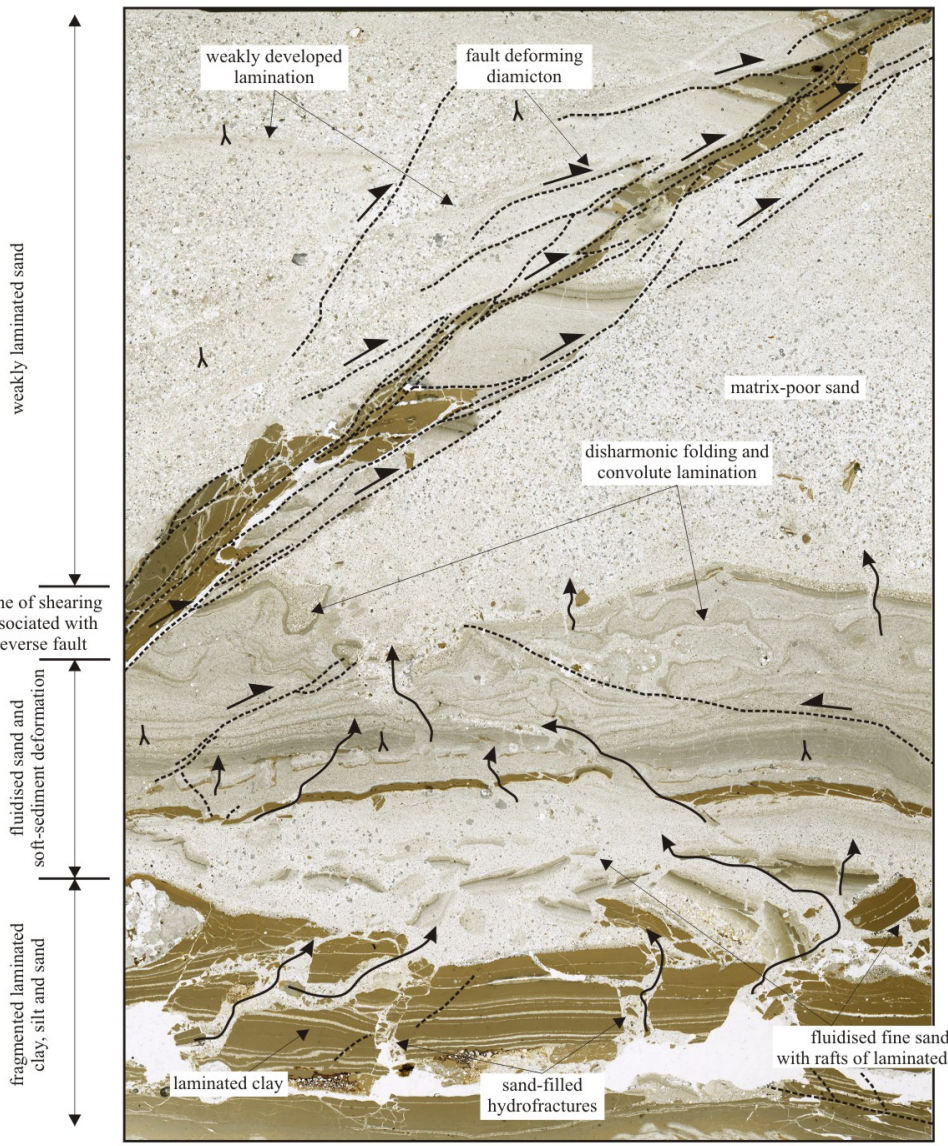

\section{Raitts Burn: S98557}

$20 \mathrm{~mm}$

$\lambda$ graded bedding indicating way-up $\quad \perp$ direction of movement on faults _... faults

sediment-filled water-escape conduits

Fig. 3 


\section{Phase of deformation}

Style of deformation

\section{compaction/}

loading

'D2'

'D3'

'D4'

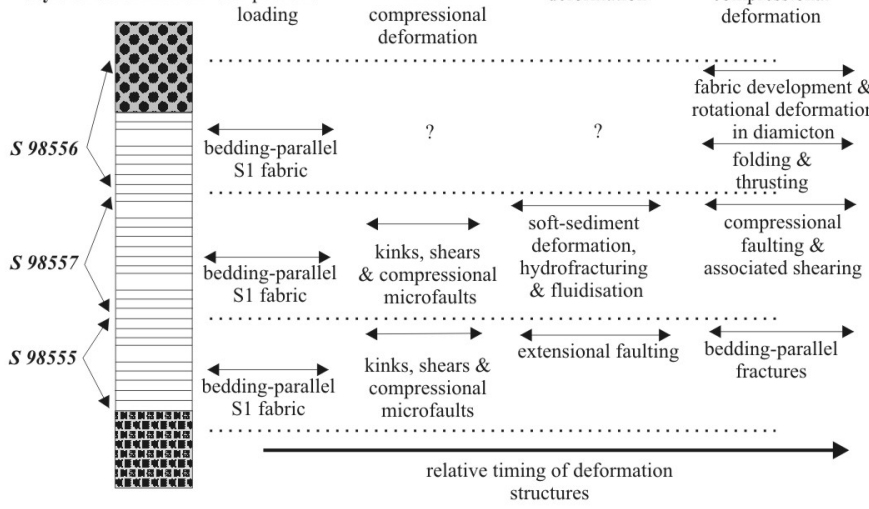

\section{Interpretation}

$\int^{1}{ }^{1}$

\section{Raitts Burn, Strathspey}

Fig. 4 


\section{Description / Interpretation}

Location: Coire Mhic-sith, Drummochter

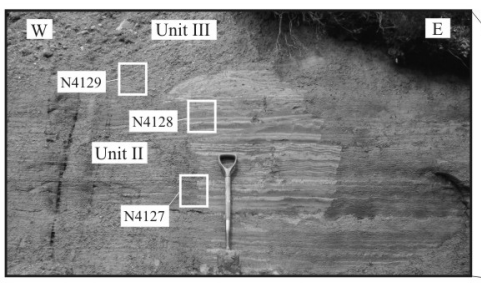

diamicton

sand, silt, clay

gravel

\section{UNIT IV $(\mathbf{G m})^{*}$}

Clast-supported cobble gravel

River terrace deposit

\section{UNIT III (Dmm)}

Extremely compact, matrix-supported, yellowish brown, very silty sandy clay diamicton

Glacigenic deposit: subglacial diamicton

\section{UNIT II (F1/Flv)}

Hard, extremely compact, planar laminated clay, silt and fine-grained sand, highly deformed with the intensity of deformation increasing upwards Over-idden glaciolacustrine sediment

\section{UNIT I (Fl/Flv)}

Stiff, rhythmically laminated yellowish brown clay, silt and very fine-grained sand

Glaciolacustrine sediment

Fig. 5 


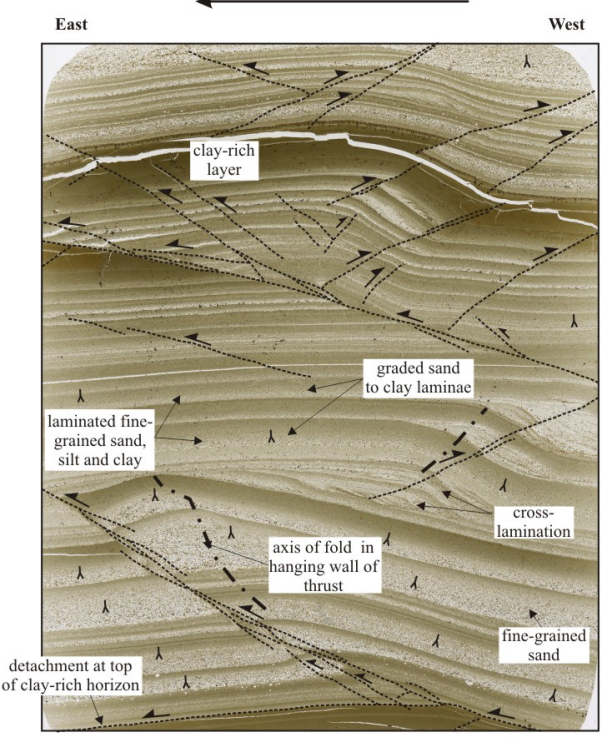

(a) Coire Mhic-sith: N4127

$\lambda$ graded bedding indicating way-up
$10 \mathrm{~mm}$

1 direction of movement on faults

\section{East}

silty clay fragments in

homogenised

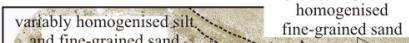

$B$ and fine-grained sand

se 8

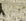
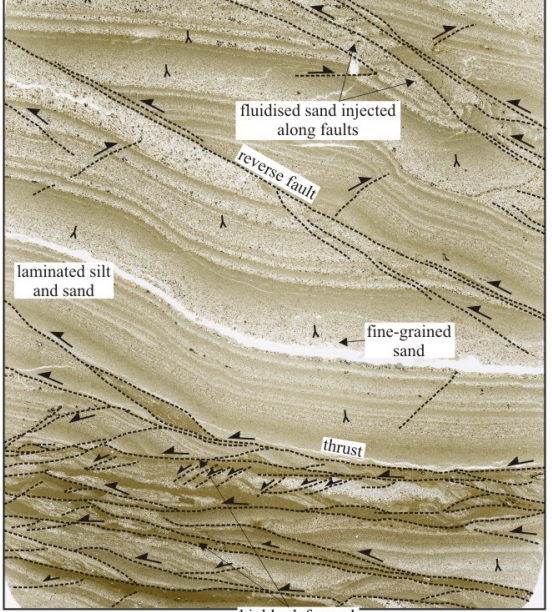

(b) Coire Mhic-sith: N4128

highly deformed

clay along thrust

$10 \mathrm{~mm}$

fold axis

|

$\ldots$ faults $\quad$ sediment-filled water-escape conduits 


\section{East}

variably homogenised silt

\section{West}

and fine-grained sand

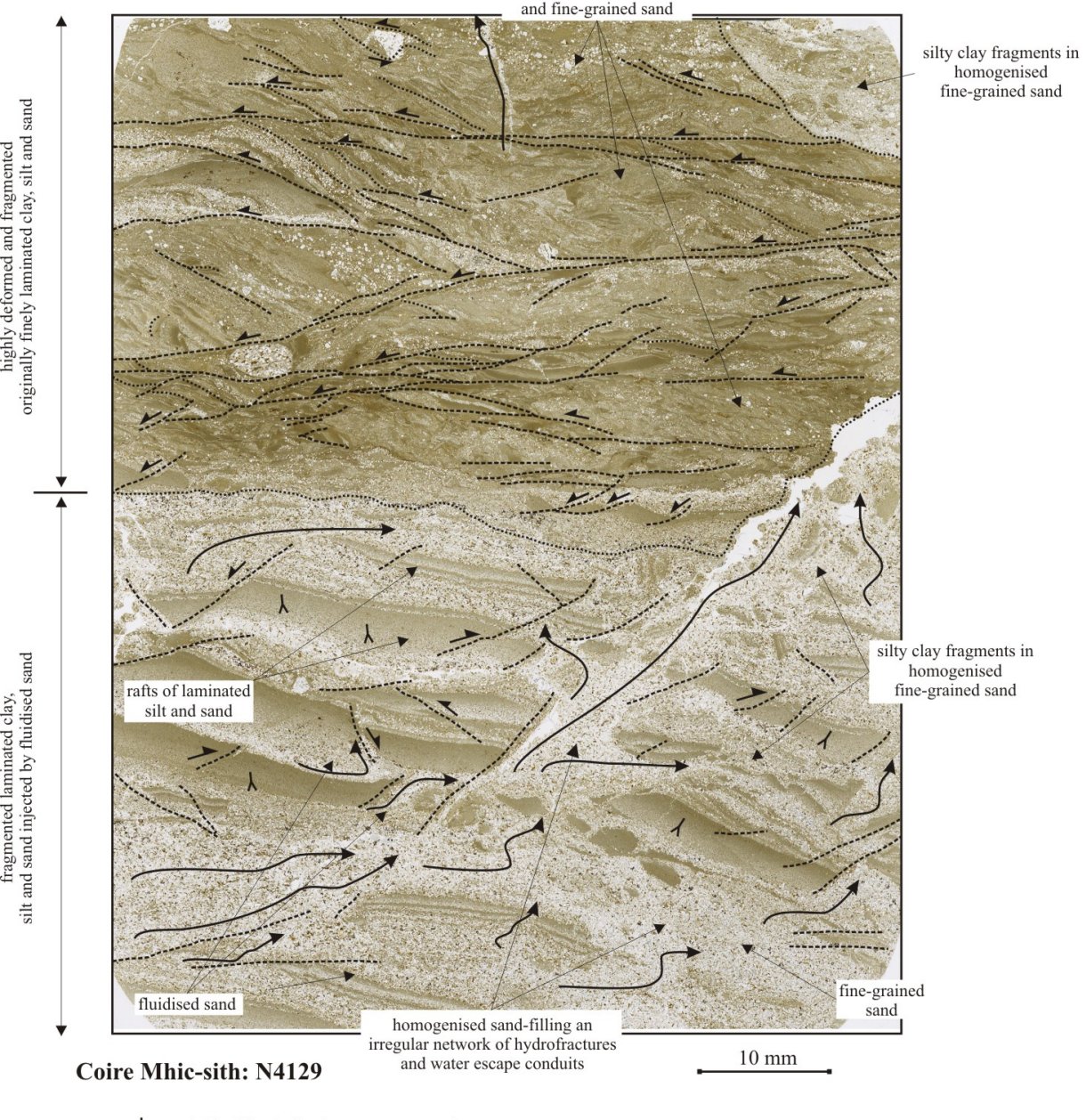

$\lambda$ graded bedding indicating way-up $\quad$ direction of movement on faults $\ldots$ faults

sediment-filled water-escape conduits

Fig. 7 


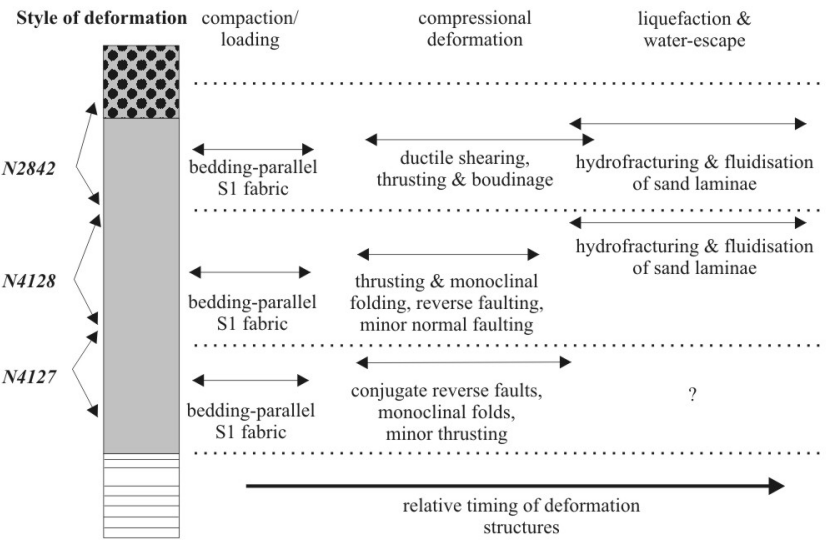

Interpretation

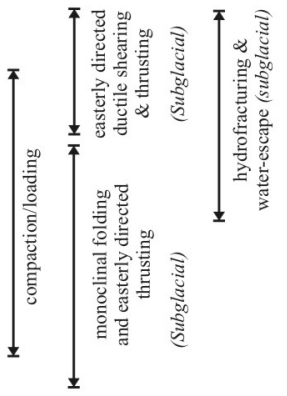

Coire Mhic-sith, Drummochter

\section{Fig. 8}




\section{Description / Interpretation}

\section{Unit VI (Dmm/Gms)*}

Massive, matrix-supported, dark yellowish brown diamicton with silt drapes over some clasts

Location: Glen Luibeg, Cairngorm Mountains

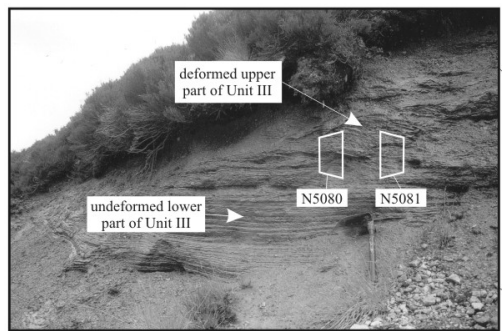

diamicton

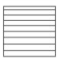

sand, silt, clay

gravel

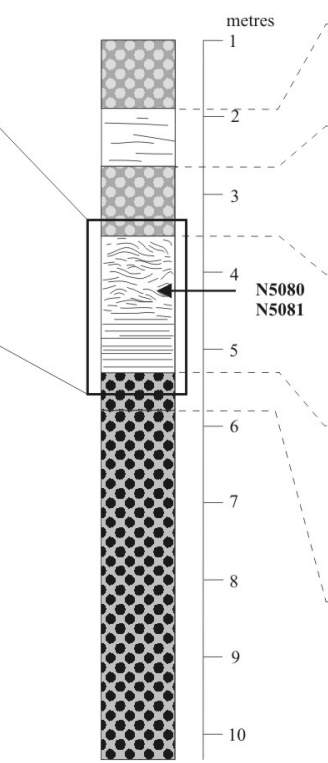

Subaqueous debris flow

\section{Unit V (Sl/FI)}

Planar bedded sand and silt

Glaciolacustrine

\section{Unit IV (Dmm/Gms)}

Massive, gravel-rich, matrixsupported, yellowish brown diamicton with a sandy matrix

Subaqueous debris flow

\section{Unit III (SI/Fl; Sd at top)}

Laminated silt and sand with some clay laminae, upper $1 \mathrm{~m}$ highly disrupted (folded, faulted, boudinage)

\section{Glaciolacustrine}

\section{Unit II (Dmm)}

Massive, matrix-supported, yellowish brown diamicton with thin beds and lenses of coarse sand

Glacigenic deposit: sub-glacial diamicton

\section{Unit I (Dmm)}

Massive, matrix-supported, reddish brown diamicton

Glacigenic deposit: sub-glacial diamicton 

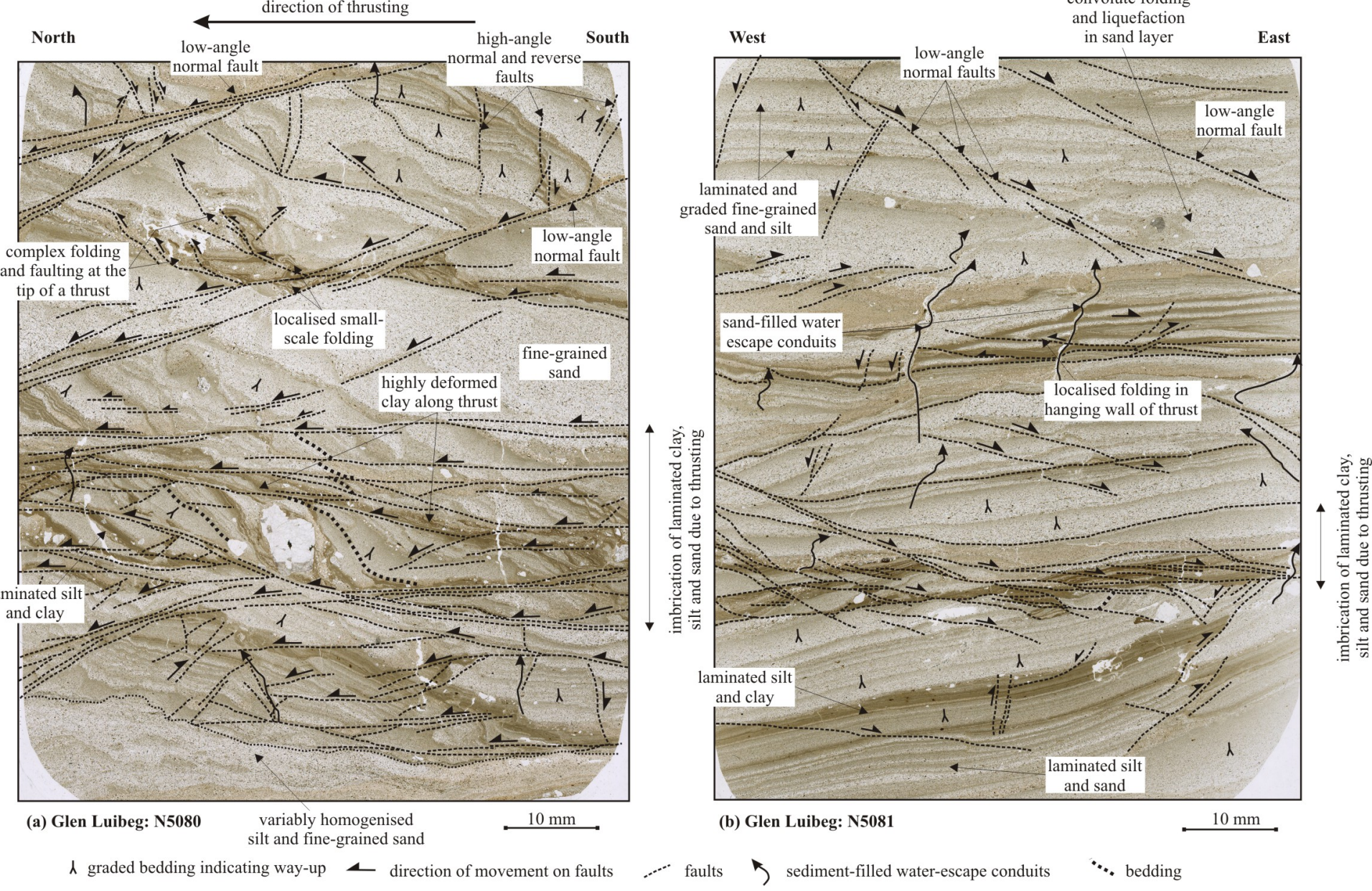


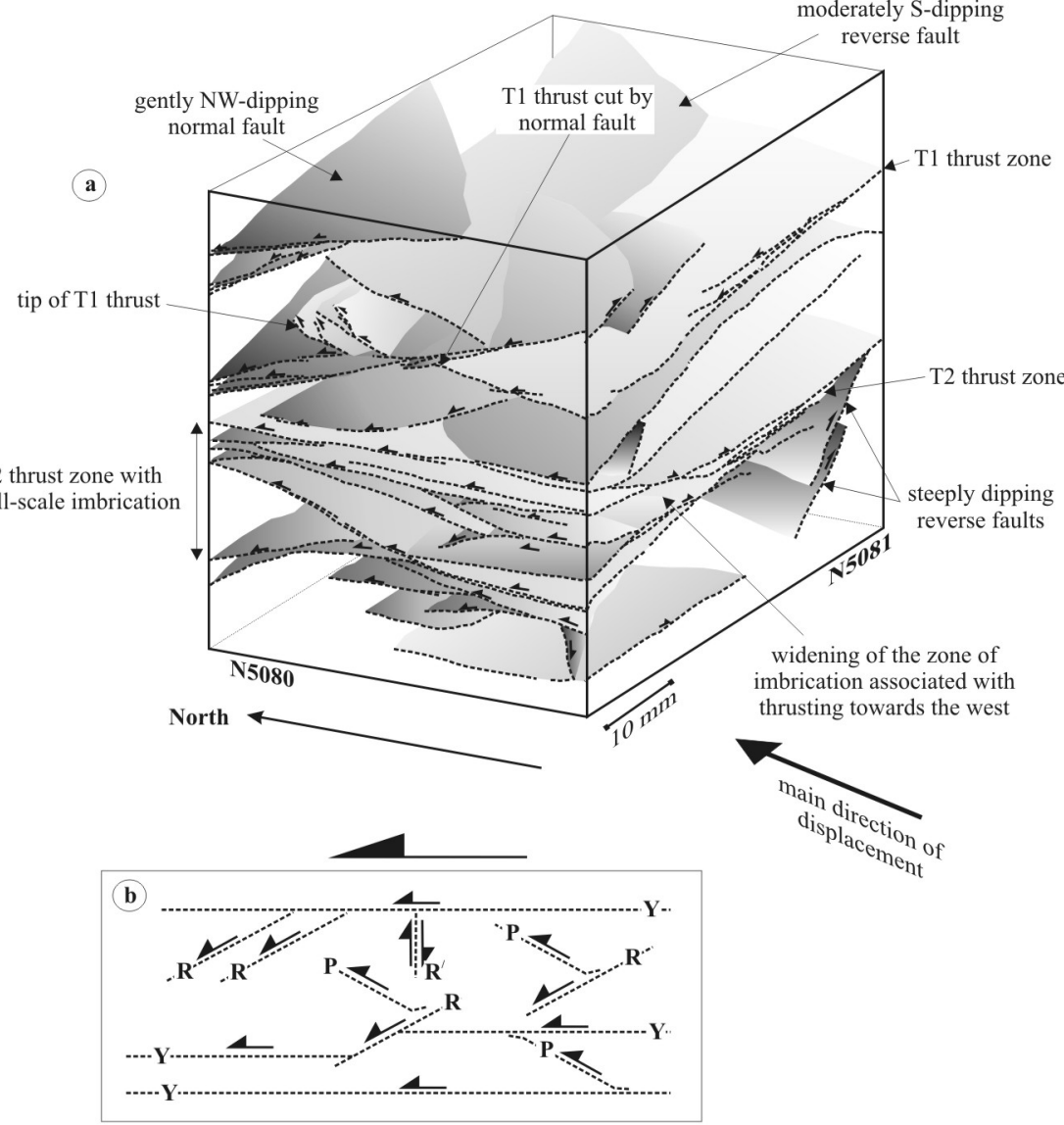

T2 thrust zone with small-scale imbrication 
Phase of deformation

Style of deformation

compaction/
loading

'D2'

'D3'

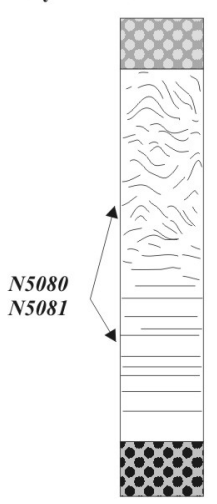

compressional

deformation

liquefaction \&

water-escape

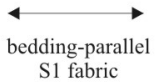

bedding-parallel

thrusting, reverse and

normal faulting

\& minor drag folding very minor

hydrofracturing

\& fluidisation relative timing of deformation structures

\section{Interpretation}

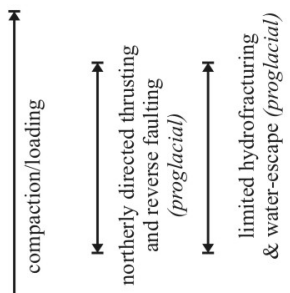

\section{Glen Luibeg, Cairngorm Mountains}

Fig. 12 


\section{Description / Interpretation}

Location: Plumpe Farm, near Gretna

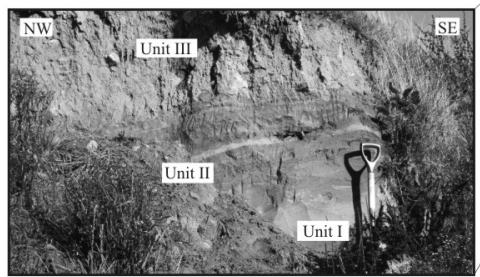

8.8 diamicton

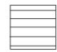

sand and silt

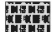

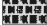

gravel

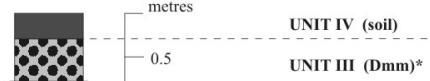

Matrix-supported, reddish brown, gravelly sandy diamicton

Glacigenic deposit: subglacial diamicton (Plumpe Bridge Till)

\section{UNIT II (Sh/FI)}

Hard, planar laminated sand, silt and silty clay

Over-ridden glaciolacustrine or

glaciofluvial sediment

\section{UNIT I (Sh/Fl)}

Compact, reddish brown silty sand and silt, uppermost $50 \mathrm{~cm}$ laminated

Glaciolacustrine or glaciofluvial sediment

\section{Fig. 13}


(a) Plumpe Farm: N2840

\section{Northwest}

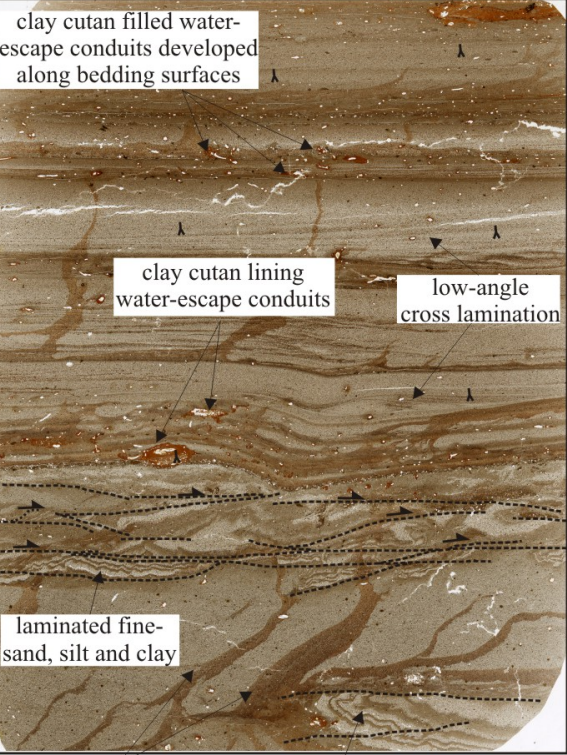

$\mathrm{Fe}$-staining of sediment recumbent fold

$10 \mathrm{~mm}$ diami

layer composed of rounded till pebbles in a clay matrix fragment of wacke sandstone
Southeast

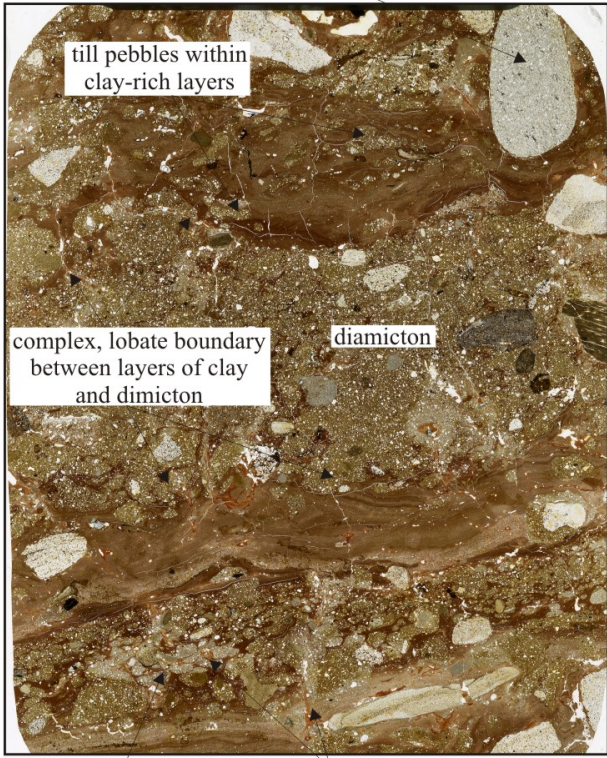

clay cutan filled water-escape conduits
$10 \mathrm{~mm}$
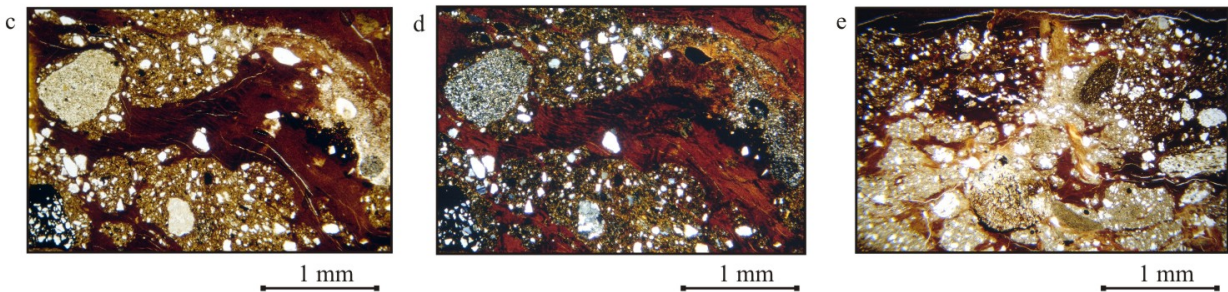

$1 \mathrm{~mm}$

$\_$direction of movement on faults ... faults

Fig. 14 

surface

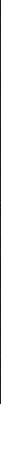

$\lambda$ way-up of sediments

.... faults

......... bedding/lithological boundaries

- sense of displacement on faults and thrusts

..... thrusts

Fig. 15 


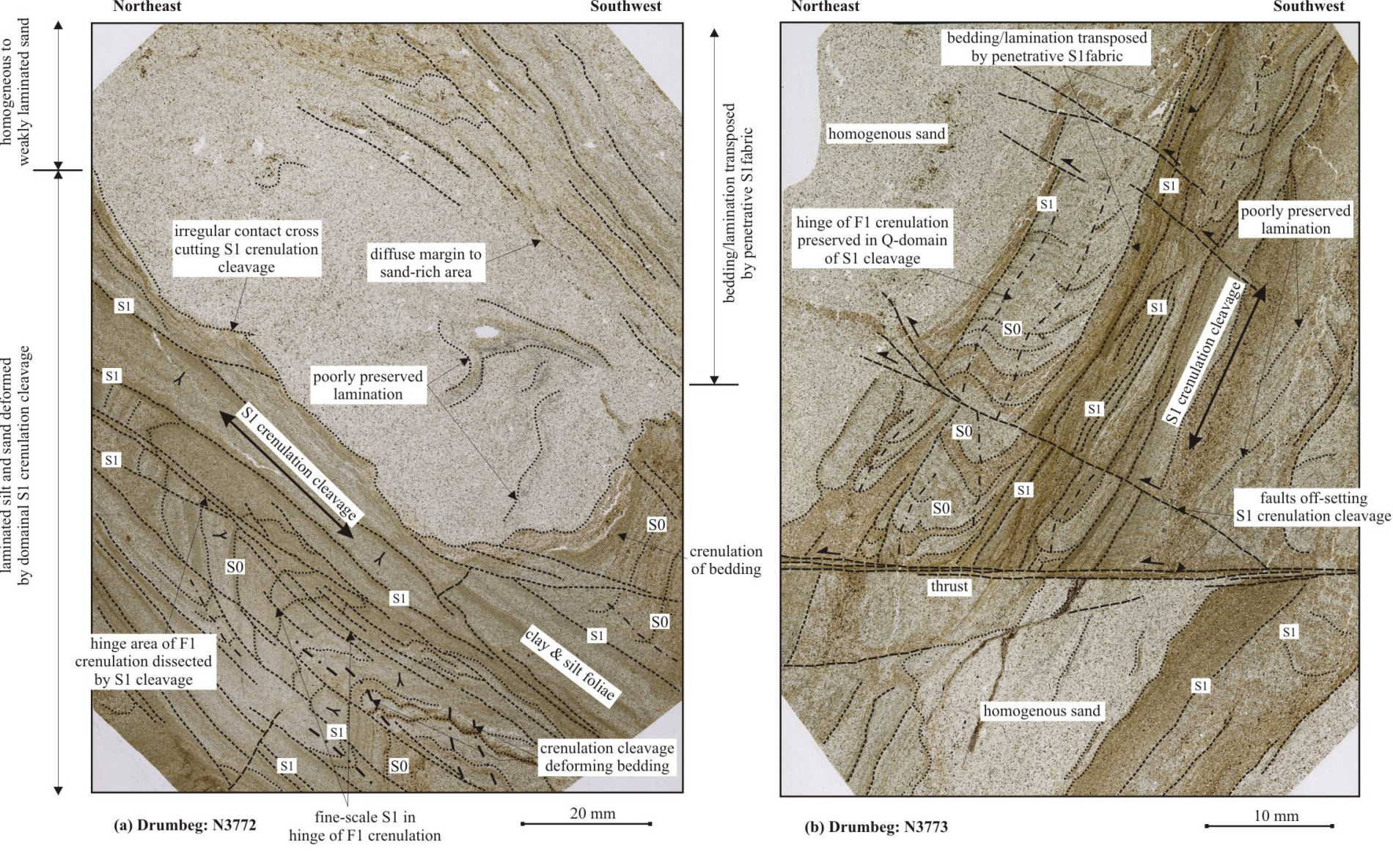

$\Lambda$ graded bedding indicating way-up _., axial surfaces to crenulation-style folds 


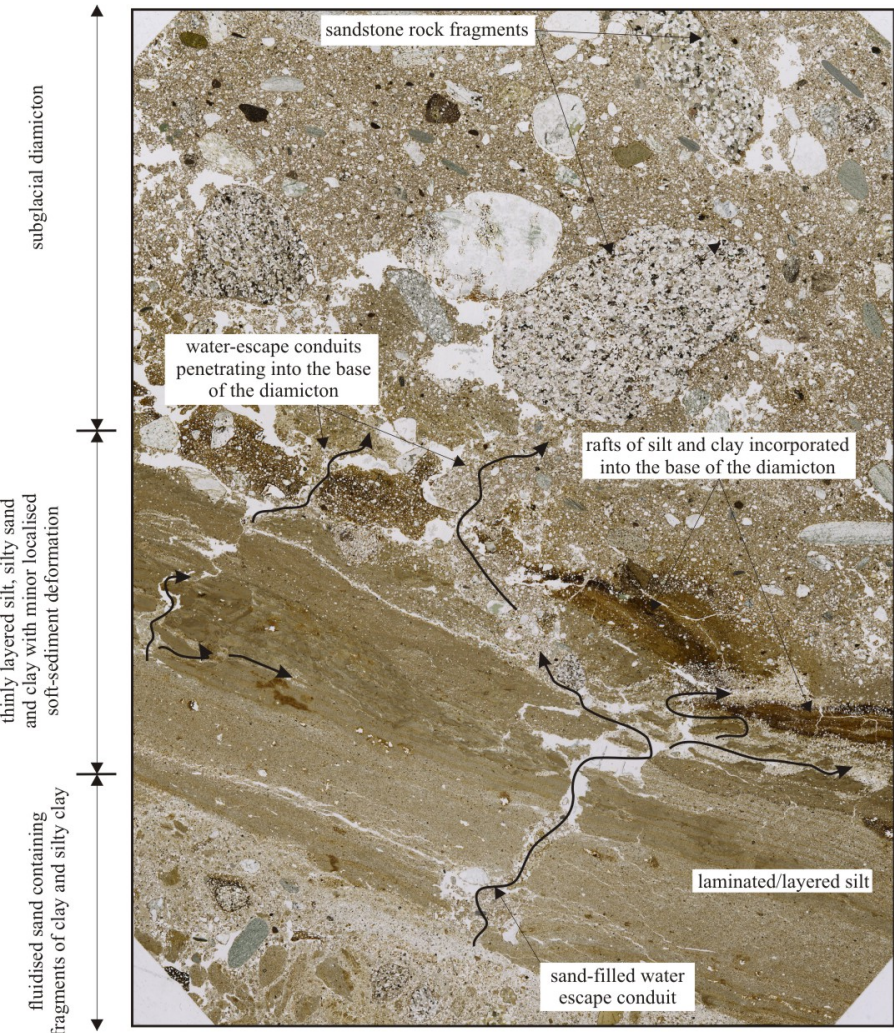

\section{Drumbeg: N3770}

sediment-filled water-escape conduits 


\section{Phase of deformation}

Interpretation

compaction loading
'D1'

progressive proglacial deformation in response to NE-directed ice movement

\section{'late syn-}

to post-D1'
'D2'

progressive subglacial deformation in response to NE-directed

overriding of the ice
'D3'

minor faulting in response to unloading

\& retreat of ice

faulting due to extension associated with retreat of ice

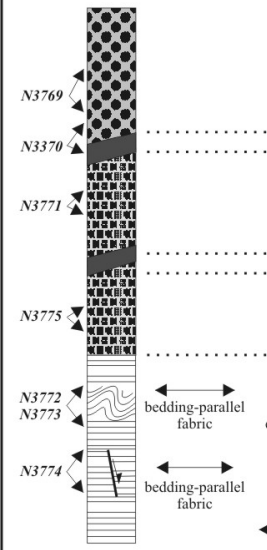

NE-directed thrusting hydrofracturing \&injection $\ldots \ldots \ldots \ldots \ldots$ of fluidised sediment into base of diamicton

ductile shearing \& injection of fluidised sediment along high strain zones

soft-sediment deformation

$\&$ liquefaction

$\ldots \ldots \ldots \ldots \ldots$

$\underset{\text { minor faulting }}{\longrightarrow}$

$\ldots \ldots \ldots \ldots \ldots \ldots \ldots \ldots$

ductile shearing along high strain zone

4 soft-sediment deformation

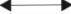

\& liquẹfaction

minor faulting

\section{S1 \\ crenulation cleavage \\ normal \& minor \\ reverse faulting}

development
$?$ normal \& minor

reverse faulting

Drumbeg Quarry, Drymen 
Table 1. Summary of the range of deformation structures developed within the deformed glacigenic sediments exposed at Raitts Burn, Coire Mhic-sith, Glen Luibeg, Plumpe Farm and Drumbeg Quarry, and their glacitectonic setting. $\sqrt{ }=$ well developed $\sqrt{ }=$ poorly developed/present.

\begin{tabular}{|c|c|c|c|c|c|c|c|c|c|}
\hline \multirow[t]{2}{*}{ Location } & \multicolumn{7}{|c|}{ Deformation Structures } & \multirow{2}{*}{$\begin{array}{c}\text { Polyphase } \\
\text { deformation } \\
\text { history }\end{array}$} & \multirow{2}{*}{$\begin{array}{l}\text { Glacitectonic } \\
\text { setting }\end{array}$} \\
\hline & 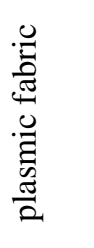 & 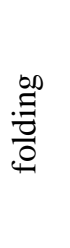 & 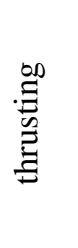 & 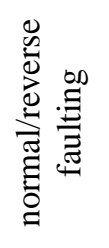 & 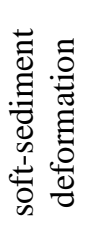 & 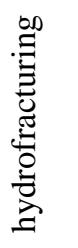 & 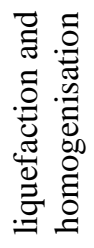 & & \\
\hline $\begin{array}{l}\text { 1. Raitts Burn, } \\
\text { Strathspey }\end{array}$ & $\sqrt{ }$ & $\sqrt{ }$ & $\sqrt{ }$ & $\sqrt{ }$ & $\sqrt{ }$ & $\sqrt{ }$ & $\sqrt{ }$ & yes & subglacial \\
\hline $\begin{array}{l}\text { 2. Coire Mhic-sith, } \\
\text { Drumochter }\end{array}$ & $\sqrt{ }$ & $\sqrt{ }$ & $\sqrt{ }$ & $\sqrt{ }$ & & $\sqrt{ }$ & $\sqrt{ }$ & yes & subglacial \\
\hline $\begin{array}{l}\text { 3. Glen Luibeg, } \\
\text { Cairngorm Mountains }\end{array}$ & $\sqrt{ }$ & $\sqrt{ }$ & $\sqrt{ }$ & $\sqrt{ }$ & & $\sqrt{ }$ & & yes & proglacial \\
\hline $\begin{array}{l}\text { 4. Plumpe Farm, near } \\
\text { Gretna }\end{array}$ & $\sqrt{ }$ & & & & $\sqrt{ }$ & & $\sqrt{ }$ & no & subglacial \\
\hline $\begin{array}{l}\text { 5a. Drumbeg Quarry, } \\
\text { near Drymen }\end{array}$ & & $\sqrt{ }$ & $\sqrt{ }$ & $\sqrt{ }$ & & & $\sqrt{ }$ & yes & proglacial \\
\hline $\begin{array}{l}\text { 5b. Drumbeg Quarry, } \\
\text { near Drymen }\end{array}$ & & & & & $\sqrt{ }$ & $\sqrt{ }$ & $\sqrt{ }$ & yes & subglacial \\
\hline
\end{tabular}

